\title{
Tegument Assembly and Secondary Envelopment of Alphaherpesviruses
}

\author{
Danielle J. Owen, Colin M. Crump and Stephen C. Graham * \\ Received: 31 May 2015 ; Accepted: 26 August 2015 ; Published: 18 September 2015 \\ Academic Editor: Eric O. Freed \\ Department of Pathology, University of Cambridge, Tennis Court Road, Cambridge CB2 1QP, UK; \\ do302@cam.ac.uk (D.J.O.); cmc56@cam.ac.uk (C.M.C.) \\ * Correspondence: scg34@cam.ac.uk; Tel.: +44-1223-333690; Fax: +44-1223-333346
}

\begin{abstract}
Alphaherpesviruses like herpes simplex virus are large DNA viruses characterized by their ability to establish lifelong latent infection in neurons. As for all herpesviruses, alphaherpesvirus virions contain a protein-rich layer called "tegument" that links the DNA-containing capsid to the glycoprotein-studded membrane envelope. Tegument proteins mediate a diverse range of functions during the virus lifecycle, including modulation of the host-cell environment immediately after entry, transport of virus capsids to the nucleus during infection, and wrapping of cytoplasmic capsids with membranes (secondary envelopment) during virion assembly. Eleven tegument proteins that are conserved across alphaherpesviruses have been implicated in the formation of the tegument layer or in secondary envelopment. Tegument is assembled via a dense network of interactions between tegument proteins, with the redundancy of these interactions making it challenging to determine the precise function of any specific tegument protein. However, recent studies have made great headway in defining the interactions between tegument proteins, conserved across alphaherpesviruses, which facilitate tegument assembly and secondary envelopment. We summarize these recent advances and review what remains to be learned about the molecular interactions required to assemble mature alphaherpesvirus virions following the release of capsids from infected cell nuclei.
\end{abstract}

Keywords: virus egress; virus maturation; herpes simplex virus; HSV-1; pseudorabies virus; $\operatorname{PrV}$

\section{Introduction}

The herpesviruses are classified into three subfamilies, the alpha-, beta- and gammaherpesviruses, all of which share a common virion morphology and a group of approximately 40 conserved genes that play key roles during virus replication [1]. Molecular phylogenetic analysis suggests that the Herpesviridae subfamilies diverged from a common ancestor around 400 million years ago and evolution over this time has given rise to at least 135 species [2,3]. The herpesviruses occupy a diverse range of biological niches, both in terms of host cell type and length of reproductive cycle. Three alphaherpesviruses are capable of infecting humans: herpes simplex virus (HSV)-1 and HSV-2, which usually cause only mild orofacial or genital lesions, respectively, but can cause more severe disease in neonates or the immunocompromised, and varicella-zoster virus (VZV), the etiological agent of chickenpox and shingles [1]. Pseudorabies virus (PrV), a swine virus that can infect other mammals including monkeys, but not higher primates or man [4], has been extensively studied as a model alphaherpesvirus.

Alphaherpesviruses are commonly defined by their ability to establish a latent infection in neurons. Primary alphaherpesvirus infection occurs in epithelial cells and is frequently asymptomatic. A lifelong infection is established when virions spread to adjacent sensory neurons, 
resulting in retrograde transport of capsids to the cell body during viral entry (Figure 1). HSV-1 infects mucosal epithelial cells and latency is established in the maxillary branch of the trigeminal ganglion, part of the peripheral nervous system [5]. During latency the viral genome is maintained in the cell nucleus; periodic reactivation of the lytic cycle leads to the assembly of new viral particles and their anterograde transport along axons to epithelial cells for symptomatic and asymptomatic shedding [6]. Anterograde trafficking and trans-neuronal spread to the central nervous system (CNS) occurs occasionally and is associated with severe disease [7].

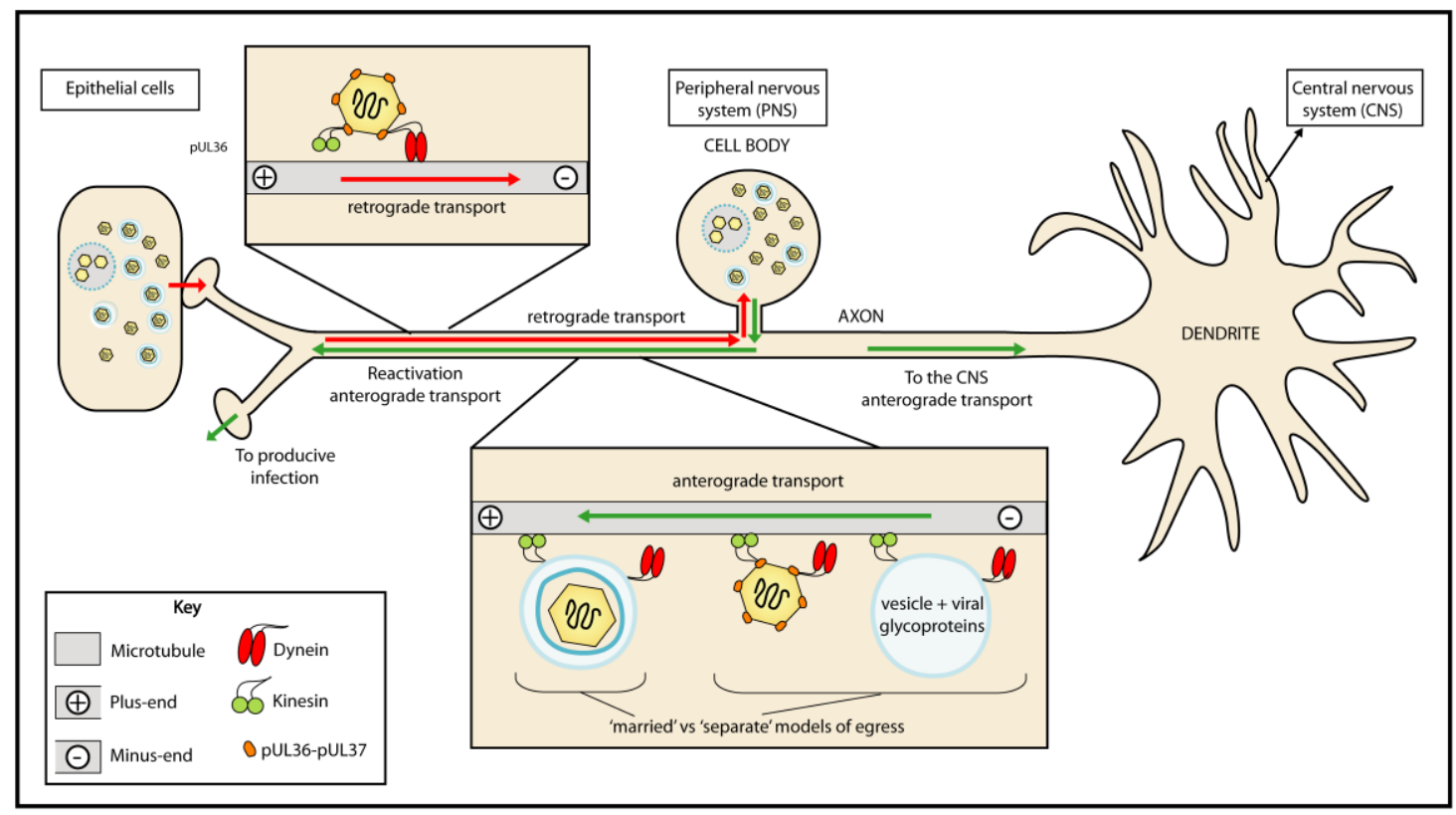

Figure 1. Neuronal trafficking during entry and egress. Alphaherpesviruses establish latent infection in the nuclei of peripheral ganglia following retrograde transport of capsids along microtubules. Reactivation results in the production of new virions that undergo anterograde trafficking back to peripheral tissues. The assembly state of viral particles prior to anterograde axonal transport is disputed and two models have been proposed: the "married model" predicts that virions are assembled in the cell body and trafficked within vesicles; the "separate model" predicts that capsids and secondary-envelopment membranes are trafficked separately with final virion assembly occurring at or near the sites of egress. Minus-end directed transport to the cell body along microtubules is driven by dynein while kinesins drive plus-end directed transport to the cell periphery. The movement of viral particles along axons during entry and egress is bidirectional and saltatory suggesting that both dynein and kinesin motor proteins may be involved. How the net direction of transport during entry and egress is determined is currently unknown.

Herpesvirus virions are organised into four morphologically distinct structures: An electron-dense core that contains the linear double-stranded DNA genome; an icosahedral capsid approximately $125 \mathrm{~nm}$ in diameter with $T=16$ symmetry and a single unique (portal) vertex through which DNA enters and leaves the capsid; a proteinaceous layer termed tegument that links the capsid to the viral envelope; and an outer envelope consisting of host-cell derived lipids, viral envelope proteins and membrane proteins from the host cell [8-11]. According to the most widely-accepted model, maturation and egress of herpes virions can be described in four stages: (1) capsid assembly and genome packaging in the nucleus; (2) primary envelopment and de-envelopment at the nuclear envelope; (3) tegumentation and secondary envelopment in the cytoplasm; and (4) exocytosis at the plasma membrane or cell-to-cell spread at cell junctions (Figure 2) [12-14]. Viral maturation occurs concomitantly with transport through the cytoplasm, as DNA-loaded capsids (so-called "C-capsids") undergo tegumentation and secondary envelopment en route to the plasma membrane. The focus 
of this review will be on the latter cytoplasmic stages of maturation, tegumentation and secondary envelopment; for reviews of nuclear egress see [12,13,15].

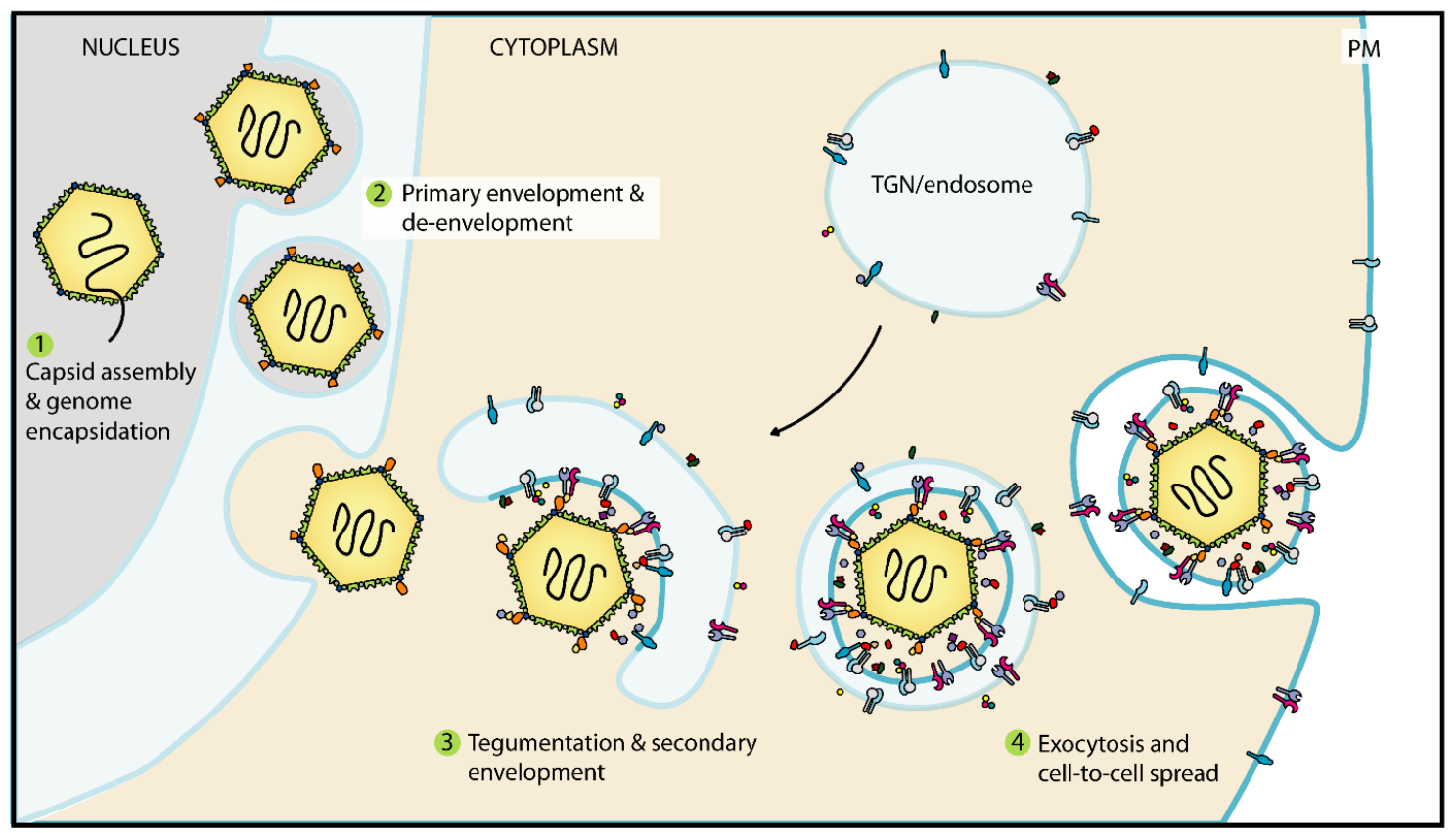

Figure 2. Maturation and egress of herpesviruses. Replication of the viral genome and encapsidation occurs in the nucleus. Once assembled, capsids interact with the inner nuclear membrane and bud into the perinuclear space where they form primary enveloped particles. The primary envelope is then lost upon fusion with the outer nuclear membrane and unenveloped capsids are released into the cytoplasm. Cytoplasmic capsids acquire tegument proteins and their membrane by budding into specialised vesicles, probably derived from endosomes or the trans-Golgi network (TGN), that are studded with viral glycoproteins and outer tegument proteins. The secondary envelopment step also provides a transport vesicle that later fuses with the plasma membrane (PM) to release enveloped virions from the cell.

\section{Tegument Form and Function: An Overview}

\subsection{Tegument Is a Dense Protein Network}

Herpesvirus tegument is a self-supporting structure comprising thousands of densely-packaged protein molecules. Proteomic analysis of extracellular HSV-1 virions by mass spectrometry identified 23 virally-encoded tegument proteins and a number of host-cell enzymes, chaperones and structural proteins, some of which are likely to be incorporated into the tegument layer [16]. HSV-1 encoded tegument proteins range in size and abundance, with the smallest predicted to be approximately 10.5 $\mathrm{kDa}$ (pUL11) and the largest greater than $330 \mathrm{kDa}$ (pUL36/VP1-2). The most abundant tegument proteins are pUL47/VP13-14, pUL48/VP16, and pUL49/VP22, which are present at 600-1300 copies per virion [17]. Among the host cell proteins identified in extracellular virions are proteins involved in trafficking and exocytosis, in particular members of the Annexin and Rab GTPase families [16]. A myriad of protein:protein interactions bind tegument proteins together so tightly that the structural integrity of this layer is largely maintained even following removal of the membrane envelope from HSV "L-particles", non-infectious capsid-less particles that are produced during alphaherpesvirus infection $[18,19]$. 


\subsection{Tegument Asymmetrically Links the Capsid to the Viral Envelope}

Tegument proteins are generally designated as belonging to either "inner" or "outer" tegument depending on their preferential association with either the capsid or viral membranes during entry and egress, and based on their fractionation behaviour after virion lysis with non-ionic detergents $[13,20,21]$. More recently the localization of specific tegument proteins within the tegument layer of individual virions has begun to be uncovered using super-resolution microscopy techniques [22]. While the outer HSV-1 tegument appears to be amorphous, the inner layer has partial icosahedral order due to its close association with capsids [23-25].

Cryo-electron tomography shows the HSV-1 capsid to be asymmetrically placed inside the viral envelope, with the tegument layer ranging in thickness from approximately $5 \mathrm{~nm}$ at the "proximal" pole to around $35 \mathrm{~nm}$ at the "distal" pole [23]. HSV-1 particle asymmetry has also been observed by super-resolution microscopy [22] and single-particle fluorescence imaging techniques have shown an asymmetric arrangement of surface glycoproteins and selected tegument proteins around the capsid of PrV virions [26]. This asymmetry is reflected in the distribution of glycoproteins on the outer membrane, with dense clusters of glycoproteins located at the thicker distal pole and relatively few glycoproteins at the proximal pole [23]. Partitioning of glycoproteins in this manner may be consistent with a lack of tegument-based anchorage at the proximal pole and/or the clustering of glycoproteins into lipid rafts. One hypothesis suggests that virion asymmetry may be established during secondary envelopment, with budding initiated at the tegument- and glycoprotein-rich distal pole $[23,27]$. During cell entry the proximal pole appears to preferentially form the fusion pore with the plasma membrane [27]. Taken together these results suggest that the two poles of the asymmetric HSV-1 virion are functionally distinct: the glycoprotein-rich distal pole mediates assembly while membrane fusion occurs predominantly at the glycoprotein-poor proximal pole [27]. It was proposed that reduced steric hindrance of entry-associated glycoproteins at the less-crowded proximal pole may give rise to an increased frequency of fusion at this pole [27], but this hypothesis has yet to be tested directly.

The icosahedral capsids of herpesviruses have a single unique vertex, termed the portal vertex, that allows DNA packaging during virion assembly and is formed by a dodecameric ring of pUL6 (HSV and PrV) or ORF54 (VZV) $[9,28]$. A tegument-spanning feature that projects from the portal vertex into the vicinity of the viral envelope and glycoprotein tails has recently been reported for HSV-1 [29]. Designated as the portal vertex associated tegument (PVAT), this feature appears to maintain a constant distance between the portal vertex and the viral membrane, meaning that for virions with a large diameter (i.e., those packaging a large amount of tegument) the portal vertex typically corresponds with the proximal pole. It is unclear whether the orientation of the capsid portal vertex with respect to the membrane helps establish virion asymmetry during secondary envelopment.

\subsection{Tegument Proteins Modulate the Host Cell Immediately Following Infection}

Aside from contributing to the structural integrity of virions, tegument proteins can perform a host of functions within the cell immediately after entry and prior to the de novo synthesis of viral proteins. For example, transcriptional activation of immediate-early genes follows the formation of a transcription complex between the host cell factors HCF-1 and Oct-1 and the HSV-1 tegument protein pUL48/VP16 or its VZV homologue ORF10 [30-34]. In HSV-1 and PrV a second tegument protein, pUL41/vhs, suppresses protein expression by degrading host mRNA during the early stages of infection and viral mRNA later in infection [35-38]. Interestingly, the VZV homologue of pUL41 (ORF17) is not packaged into virions and doesn't mediate host gene shutoff $[39,40]$.

Infected cell protein 0 (ICP0) is an immediate-early protein that modulates the host's innate and intrinsic responses to infection (reviewed in [41,42]). The RING domain of ICP0 possesses E3 ubiquitin ligase activity and ICP0 targets several cellular and viral proteins for proteasome-mediated degradation. For example, ICP0 directs the degradation of DNA-PKcs [43], part of the cellular DNA 
damage response that acts as a cellular sensor of DNA virus infection and potentiates interferon production [44]. ICP0 also disrupts nuclear domain 10 (ND10), also known as nuclear bodies or promyelocytic leukemia protein (PML) bodies, and in doing so disrupts their ability to restrict viral gene expression [41]. ORF61 of VZV is a functional homologue of ICP0 and is able to complement a HSV-1 ICP0 deletion mutant in tissue culture [45]. Similarly, growth defects of the PrV EP0 deletion mutant can be complemented by cells expressing the VZV or HSV-1 ICP0 homologues [46]. ICP0 is incorporated into tegument via its interaction with pUL49 [47], although the exact contribution of de novo synthesised versus tegument-delivered ICP0 protein in newly infected cells remains to be elucidated [41].

\subsection{Tegument helps Deliver viral Genomes to the Nuclei of Infected Cells}

In addition to modulating the immune system of newly infected cells, tegument proteins direct microtubule-mediated retrograde transport of capsids to the nucleus (reviewed in [48]) and nuclear entry of the viral DNA genome. During entry, HSV-1 and PrV capsids undergo bidirectional and saltatory movement along microtubules with the net retrograde motility directed towards the nucleus [49-54]. Bidirectional transport along microtubules suggests that both dynein and kinesin motor proteins may be recruited to incoming capsids [51,55]. Furthermore, dynein and its cofactor dynactin, kinesin- 1 and kinesin-2 co-purify with partially tegumented HSV-1 capsids extracted from extracellular virions following incubation with cytosolic extracts [20]. The most likely candidates for recruiting motor proteins are pUL36/VP1-2 and pUL37, since they remain bound to capsids during transit and are able to recruit motor proteins in vitro [20,54,56-62]. A role for pUL36 in retrograde trafficking is supported by the observation that the deletion of the C-terminal 167 residues of HSV-1 pUL36 abolishes directed transport towards the nucleus [62]. Recently, an interaction between pUL36 and the dynein/dynactin motor complex (involved in retrograde transport) has been shown to promote the transport of PrV capsids during entry [63]. While pUL37 has been shown to enhance retrograde trafficking in $\operatorname{PrV}$ it is not essential for capsid transport during entry [64].

After trafficking to the nucleus capsids dock and release their DNA genome at nuclear pore complexes (NPCs). Efficient binding of purified capsids to NPCs in an in vitro assay was shown to be impaired following the removal of inner and outer tegument proteins by trypsinization [65]. Antibodies targeted against pUL36-but not pUL37, pUL19/VP5 or pUL18/VP23-are able to attenuate capsid attachment at NPCs, suggesting that pUL36 is involved during docking [66]. HSV-1 pUL36 is required for the release of viral DNA from capsids into the nucleus, as demonstrated by a temperature-sensitive HSV-1 virus (tsB7) carrying four point mutations in UL36: at a non-permissive temperature capsids accumulated at nuclear pores but failed to release their DNA [67,68]. Further, a study using artificially-induced syncytia formation showed that nascent viral particles produced by a UL36 HSV-1 deletion virus were unable to infect other nuclei within a syncytium [69]. In contrast, deletion of UL37 didn't prohibit infection of other nuclei [69]. The capsid protein pUL25 interacts with pUL36, the capsid portal vertex protein PUL6 and the nuclear pore complex protein CAN/Nup214 [70]. The interaction between pUL25 and CAN/Nup214 is also thought to stimulate the release of viral DNA from capsids through nuclear pores into the nucleus of newly-infected cells [70].

\subsection{Tegumentation and Secondary Envelopment Occurs During Virion Maturation}

Herpesvirus virions comprise a complex web of protein:protein interactions between capsid, tegument and membrane-associated viral proteins including surface glycoproteins [71-74]. The assembly of tegument on capsids occurs predominantly in the cytoplasm following nuclear egress. Partial nuclear localization of tegument proteins pUL36/VP1-2, pUL37, pUL41/vhs, pUL47/VP13-14 pUL48/VP16, pUL49/VP22 has been reported in some studies, but not corroborated in others, and it is unclear whether these proteins associate with capsids within the nucleus $[13,62,75-81]$. HSV-1 ICP0 and ICP4 have been detected on purified nuclear C-capsids [82], although this finding 
is contradicted by other studies [20,47,83]. During virion maturation the inner tegument layer can be observed accumulating on cytoplasmic capsids [84]; outer tegument proteins are targeted to secondary envelopment sites, containing trans-Golgi network (TGN) or endosomal markers, by post-translational lipid modifications or by interacting with the cytoplasmic tails of viral glycoproteins [85-87].

During secondary envelopment capsids bud into specialized vesicles containing the glycoproteins that will decorate the surface of mature virions. This process simultaneously provides the viral envelope and also packages the virus into vesicles that later fuse at the plasma membrane. Tegument proteins contribute to this process by forming a network of interactions that bridge the capsid and viral membrane by interacting directly with capsid proteins, with other soluble tegument proteins, and with the cytoplasmic tails of viral glycoproteins or membrane-associated tegument proteins. HSV-1 L-particles, which contain most tegument proteins and all glycoproteins but lack capsids, follow similar assembly and egress pathways to infectious HSV-1 particles, providing evidence that tegument and glycoproteins together are sufficient to drive secondary envelopment [88-90].

\section{Conserved Protein:Protein Interactions Mediate Tegument Assembly}

Several tegument proteins have been implicated in HSV-1 and PrV secondary envelopment, largely due to the effect of deleting genes encoding these proteins on virus maturation. As shown in Table 1, seven of these genes (UL7, UL11, UL16, UL21, UL36, UL37 and UL51) are conserved in all three herpesvirus subfamilies, while four are unique to the alphaherpesviruses (UL46, UL47, UL48, UL49) [71]. The complex network of protein:protein interactions mediated by its components gives tegument a redundancy that makes characterizing the precise function(s) of any individual protein difficult. In cell culture this redundancy enables the virus to adapt to the deletion of some "non-essential" tegument proteins by increasing the incorporation of other tegument proteins, or of cellular proteins such as actin, into the virion [91-93]. While the deletion of many non-essential tegument proteins can often be tolerated there is usually a mild replication defect; a study of $\operatorname{PrV}$ shows that the severity of such growth defects in cell culture typically correlates with a proportional increase in mean survival times of infected mice [94]. Despite the challenges, recent studies have begun to elucidate the distinct contributions to secondary envelopment and virus egress made by the tegument proteins conserved across alphaherpesviruses and to map the protein:protein interactions that underpin these functions (illustrated in Figure 3 and summarised in Table 2).

Table 1. Herpesvirus tegument genes and their homologues. HSV, herpes simplex virus; VZV, varicella-zoster virus; PrV, pseudorabies virus; HCMV, human cytomegalovirus; EBV, Epstein-Barr virus; KSHV, Kaposi's sarcoma-associated herpesvirus. Virus subfamily [Alpha-, Beta- or Gamma-herpesvirinae] and alternative protein names (in parentheses) are shown.

\begin{tabular}{|c|c|c|c|c|c|c|}
\hline HSV-1/-2 [Alpha] & $\begin{array}{l}\text { Mass of HSV } \\
\text { Protein, kDa }\end{array}$ & VZV $[A l p h a]$ & $\operatorname{PrV}[A l p h a]$ & $\begin{array}{l}\text { HCMV } \\
{[\text { Beta] }}\end{array}$ & $\begin{array}{c}\text { EBV } \\
{[\text { Gamma }]}\end{array}$ & $\begin{array}{c}\text { KSHV } \\
\text { [Gamma] }\end{array}$ \\
\hline \multicolumn{7}{|c|}{ Tegument proteins involved in tegumentation and secondary envelopment } \\
\hline UL7 & 33 & ORF53 & UL7 & UL103 & BBRF2 & ORF42 \\
\hline UL11 & 10 & ORF49 & UL11 & UL99 & BBLF1 & ORF38 \\
\hline UL16 & 40 & ORF44 & UL16 & UL94 & BGLF2 & ORF33 \\
\hline UL21 & 58 & ORF38 & UL21 & UL87 & BcRF1 & ORF24 \\
\hline UL36 (VP1-2) & 336 & ORF22 (p22) & UL36 & UL48 & BPLF1 & ORF64 \\
\hline UL37 & 121 & ORF21 & UL37 & UL47 & BOLF1 & ORF63 \\
\hline UL51 & 25 & ORF7 & UL51 & UL71 & BSRF1 & ORF55 \\
\hline UL46 (VP11-12) & 78 & ORF12 & UL46 & - & - & - \\
\hline UL47 (VP13-14) & 74 & ORF11 & UL47 & - & - & - \\
\hline UL48 (VP16) & 54 & ORF10 & UL48 & - & - & - \\
\hline UL49 (VP22) & 32 & ORF9 & UL49 & - & - & - \\
\hline
\end{tabular}


Table 1. Cont.

\begin{tabular}{|c|c|c|c|c|c|c|}
\hline HSV-1/-2 [Alpha] & $\begin{array}{l}\text { Mass of HSV } \\
\text { Protein, kDa }\end{array}$ & VZV [Alpha] & $\operatorname{PrV}[A l p h a]$ & $\begin{array}{l}\text { HCMV } \\
{[\text { Beta] }}\end{array}$ & $\begin{array}{c}\text { EBV } \\
{[\text { Gamma }]}\end{array}$ & $\begin{array}{c}\text { KSHV } \\
\text { [Gamma] }\end{array}$ \\
\hline \multicolumn{7}{|c|}{ Other tegument proteins } \\
\hline UL13 (VP18.8) & 57 & ORF47 & UL13 (VP18.8) & UL97 & BGLF4 & ORF36 \\
\hline UL14 & 24 & ORF46 & UL14 & UL95 & BGLF3 & ORF34 \\
\hline $\begin{array}{l}\text { UL23 (thymidine } \\
\text { kinase) }\end{array}$ & 41 & ORF36 & TK & - & BXLF2 & ORF21 \\
\hline UL41 (vhs) & 55 & ORF17 & UL41 & - & - & - \\
\hline UL50 (dUTPase) & 39 & ORF8 & UL50 & - & - & - \\
\hline UL55 & 20 & ORF3 & - & - & - & - \\
\hline US2 & 32 & - & - & - & - & - \\
\hline US3 & 53 & ORF66 & US3 & - & - & - \\
\hline US10 & 34 & ORF64/69 & - & - & - & - \\
\hline US11 & 18 & - & - & - & - & - \\
\hline RL1 (ICP34.5) & 26 & - & - & - & - & - \\
\hline RL2 (ICP0) & 78 & ORF61 & EP0 (ICP0) & - & - & - \\
\hline RS1 (ICP4) & 133 & $\begin{array}{l}\text { ORF62/71 } \\
\text { (IE62) }\end{array}$ & IE180 (ICP4) & - & - & - \\
\hline
\end{tabular}

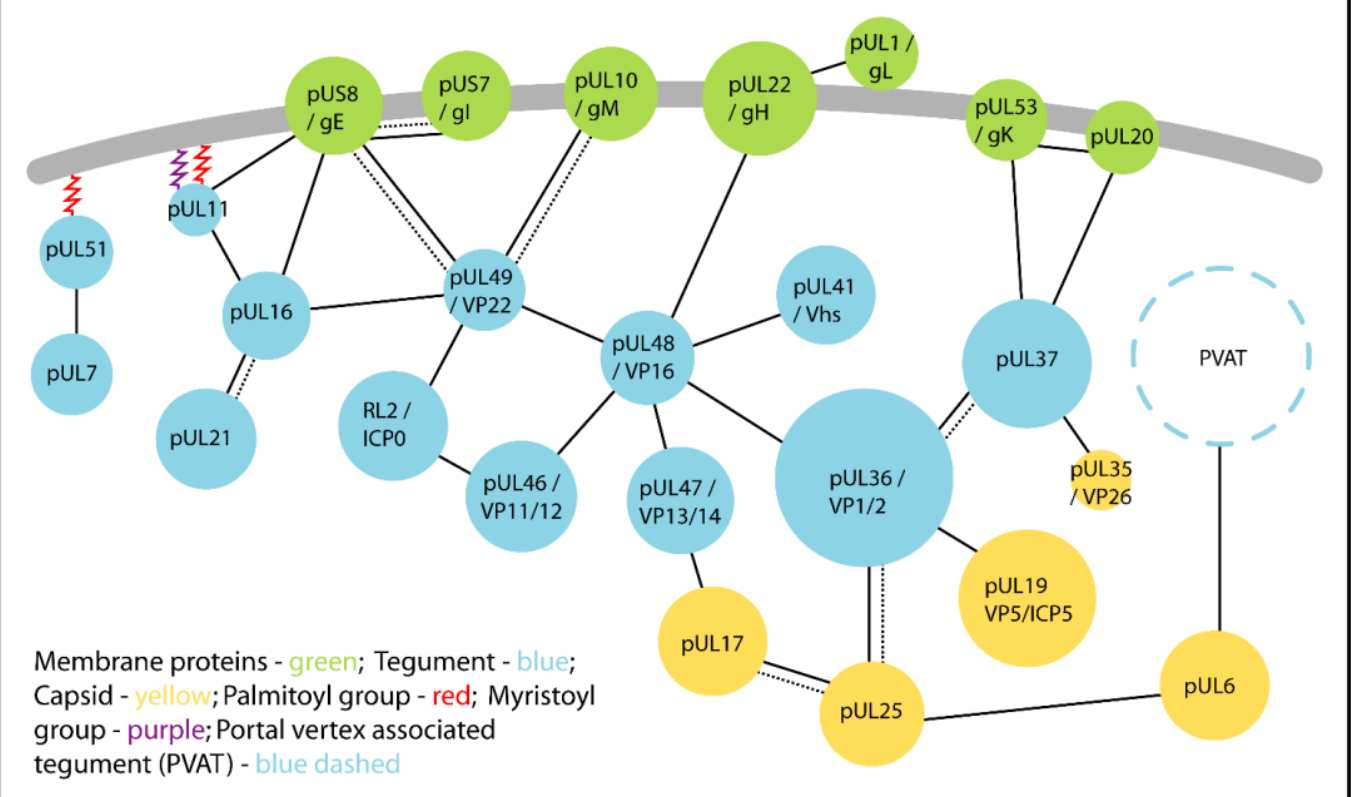

Figure 3. Conserved alphaherpesvirus tegument proteins (blue) link the capsid (yellow) to the glycoproteins and envelope proteins (green) embedded in the virion lipid bilayer envelope (grey). Tegument assembles via a dense network of protein:protein interactions: solid lines indicate interactions demonstrated in HSV and dashed lines show interactions demonstrated for PrV. Some tegument proteins associate directly with the envelope via post-translational modifications conferring lipophilic palmitoyl (red) or myristoyl (purple) groups. The proteins that comprise the portal vertex associated tegument (PVAT) are currently undefined. 
Table 2. Herpesvirus tegument protein interactions that mediate secondary envelopment.

\begin{tabular}{|c|c|c|c|c|}
\hline Protein & $\begin{array}{l}\text { Other } \\
\text { Names }\end{array}$ & Interaction Partners & Function & References \\
\hline pUL7 & - & pUL51 [HSV-1] & $\begin{array}{l}\text { Putative role in cell-to-cell spread and } \\
\text { secondary envelopment. }\end{array}$ & [95] \\
\hline \multirow{2}{*}{ pUL11 } & \multirow[t]{2}{*}{-} & pUL16 [HSV-1] & $\begin{array}{l}\text { Role in secondary envelopment, also } \\
\text { enhances interaction of pUL16 with gE. } \\
\text { A tripartite complex of pUL11, pUL16 } \\
\text { and pUL21 is proposed to play a role in } \\
\text { cell fusion during syncytia formation, } \\
\text { possibly through the interaction with } \\
\text { gE. }\end{array}$ & [96-98] \\
\hline & & gE [HSV-1] & $\begin{array}{l}\text { Cell-to-cell spread and cell fusion } \\
\text { during syncytia formation. } \\
\text { Glycoprotein E accumulates at the } \\
\text { plasma membrane in the presence of } \\
\text { pUL11, pUL16 and pUL21, in a } \\
\text { cell-type dependent manner. Possible } \\
\text { role in secondary envelopment. }\end{array}$ & [99-101] \\
\hline \multirow{4}{*}{ pUL16 } & \multirow{4}{*}{-} & pUL11 & (See pUL11) & \\
\hline & & $\begin{array}{c}\text { pUL21 [HSV-1 and } \\
\text { PrV] }\end{array}$ & $\begin{array}{l}\text { pUL21 enhances the interaction } \\
\text { between pUL16 and pUL11 in } \\
\text { triple-transfected cells. Putative role in } \\
\text { cell-to-cell spread, syncitia formation } \\
\text { and secondary envelopment when in } \\
\text { complex with pUL11 and gE. }\end{array}$ & {$[98,101,102]$} \\
\hline & & gE [HSV-1] & $\begin{array}{l}\text { Putative roles in cell-to-cell spread, cell } \\
\text { fusion and secondary envelopment. } \\
\text { The interaction is enhanced in the } \\
\text { presence of pUL11 in transfected cells. }\end{array}$ & {$[101,103]$} \\
\hline & & pUL49 [HSV-1] & $\begin{array}{c}\text { Putative role in secondary } \\
\text { envelopment. }\end{array}$ & [104] \\
\hline pUL21 & - & pUL16 & (See pUL16) & \\
\hline \multirow{4}{*}{ pUL36 } & \multirow{4}{*}{ VP1-2 } & pUL19/VP5 [HSV-1] & $\begin{array}{l}\text { Links the capsid and tegument, } \\
\text { essential for tegumentation and } \\
\text { secondary envelopment. }\end{array}$ & {$[24,25,105]$} \\
\hline & & $\begin{array}{c}\text { pUL25 [HSV-1 and } \\
\text { PrV] }\end{array}$ & $\begin{array}{l}\text { Links the capsid and tegument. May be } \\
\text { required for stabilisation of the CVSC } \\
\text { of nuclear and cytoplasmic capsids. } \\
\text { Enhances dynein-mediated transport } \\
\text { during PrV entry. }\end{array}$ & $\begin{array}{c}{[62,63,70,106,} \\
107]\end{array}$ \\
\hline & & $\begin{array}{c}\text { pUL37 }[\mathrm{HSV}-1 \text { and } \\
\text { PrV] }\end{array}$ & $\begin{array}{l}\text { Provides a scaffold for tegumentation } \\
\text { and secondary envelopment. } \\
\text { Implicated in enhancing } \\
\text { microtubule-based transport during } \\
\text { entry and egress. }\end{array}$ & {$[74,75,108,109]$} \\
\hline & & pUL48 [HSV-1] & $\begin{array}{l}\text { Contributes to virus assembly. Both } \\
\text { proteins are essential in HSV-1 but this } \\
\text { is not an essential interaction. }\end{array}$ & {$[74,110,111]$} \\
\hline \multirow{4}{*}{ pUL37 } & \multirow{4}{*}{ ICP32 } & pUL36 & (See pUL36) & \\
\hline & & pUL35/VP26 [HSV-1] & $\begin{array}{c}\text { Minor role in recruiting pUL37 to } \\
\text { capsids. }\end{array}$ & {$[72,112]$} \\
\hline & & gK [HSV-1] & $\begin{array}{c}\text { Putative role in secondary envelopment } \\
\text { by linking capsid associated pUL37 } \\
\text { with the membrane associated complex } \\
\text { gK-pUL20. }\end{array}$ & [113] \\
\hline & & pUL20 [HSV-1] & $\begin{array}{l}\text { Putative role in secondary envelopment } \\
\text { by linking capsid associated pUL37 } \\
\text { with the membrane associated complex } \\
\text { gK-pUL20. }\end{array}$ & [113] \\
\hline
\end{tabular}


Table 2. Cont.

\begin{tabular}{|c|c|c|c|c|}
\hline Protein & $\begin{array}{c}\text { Other } \\
\text { Names }\end{array}$ & Interaction Partners & Function & References \\
\hline \multirow{3}{*}{ pUL46 } & \multirow{3}{*}{ VP11-12 } & $\begin{array}{l}\text { pUL48 [HSV-1 and } \\
\text { HSV-2] }\end{array}$ & $\begin{array}{l}\text { May regulate pUL48-dependent } \\
\text { transcription of immediate-early genes. }\end{array}$ & {$[74,114]$} \\
\hline & & ICP0 [HSV-1] & $\begin{array}{l}\text { E3 ligase activity of ICP0 mediates the } \\
\text { partial degradation of pUL46 during } \\
\text { infection, which may potentiate a shift } \\
\text { from immediate-early }(\alpha) \text { to early }(\beta) \\
\text { and late }(\gamma) \text { viral gene expression. }\end{array}$ & [115] \\
\hline & & $\begin{array}{l}\text { Many identified in } \\
\text { yeast two-hybrid } \\
\text { screens }\end{array}$ & Unknown. & {$[72,74,116]$} \\
\hline \multirow{3}{*}{ pUL47 } & \multirow{3}{*}{ VP13-14 } & pUL48 [HSV-1] & $\begin{array}{l}\text { Regulation of pUL48-dependent } \\
\text { transcription of immediate-early genes. }\end{array}$ & {$[110,117]$} \\
\hline & & pUL17 [HSV-1] & $\begin{array}{l}\text { May provide a link between the capsid } \\
\text { and tegument. }\end{array}$ & [118] \\
\hline & & $\begin{array}{l}\text { Many identified by } \\
\text { yeast two-hybrid } \\
\text { screen }\end{array}$ & Unknown. & [116] \\
\hline \multirow{8}{*}{ pUL48 } & \multirow{8}{*}{ VP16/ICP25 } & pUL36 & (See pUL36) & \\
\hline & & pUL41/vhs [HSV-1] & $\begin{array}{l}\text { pUL48 inhibits pUL41 during late stage } \\
\text { of infection to spare viral mRNAs from } \\
\text { degradation by pUL41. }\end{array}$ & {$[110,119-122]$} \\
\hline & & pUL46 & (See pUL46) & \\
\hline & & pUL47 & (see pUL47) & \\
\hline & & pUL49 [HSV-1] & Contributes to tegument assembly. & {$[110,123]$} \\
\hline & & gH [HSV-1] & $\begin{array}{c}\text { May contribute to secondary } \\
\text { envelopment. }\end{array}$ & {$[124-126]$} \\
\hline & & gD [HSV-1] & Unknown. & [126] \\
\hline & & gB [HSV-1] & Unknown. & [126] \\
\hline \multirow{5}{*}{ pUL49 } & \multirow{5}{*}{ VP22 } & pUL16 & (See pUL16) & \\
\hline & & pUL48 & (See pUL48) & \\
\hline & & ICP0 [HSV-1] & Packaging of ICP0 into virions. & {$[47,127]$} \\
\hline & & gE [HSV-1 and PrV] & Contributes to secondary envelopment. & {$[99,128-130]$} \\
\hline & & gM [HSV-1 and PrV] & Contributes to secondary envelopment. & {$[129,130]$} \\
\hline pUL51 & - & pUL7 & (See pUL7) & \\
\hline
\end{tabular}

\section{1. pUL36/VP1-2 Interacts with Capsid Protein pUL19/VP5 and Capsid Vertex-Specific Component Proteins $p$ UL17 and pUL25}

The pUL36 protein acts as a foundation stone for tegument assembly by providing a pivotal link between the capsid and tegument structures. The absence of pUL36 from HSV-1 and PrV blocks egress by preventing tegumentation and secondary envelopment, resulting in the accumulation of naked capsids in the cytoplasm [62,131,132]. The major capsid protein of HSV-1 and PrV is pUL19/VP5, which forms pentamers (termed pentons) at the vertices of the icosahedral capsid and hexamers (termed hexons) on the icosahedral faces [10,133-135]. Six copies of pUL35/VP26 bind pUL19/VP5 to form a cap that sits over the hexons, and between each penton and hexon are triplexes formed by the proteins pUL38/VP19C and pUL18/VP23 [10,134]. Cryo-electron microscopy (cryo-EM) analysis of C-capsids from mature virions shows pUL36 interacting with the major capsid protein pUL19/VP5 at capsid vertices where it binds between two penton protrusions to form a cap over the penton vertex (Figure 4) [24,25,105]. While addition of pUL36 to capsids had previously been considered to occur in the cytoplasm shortly after nuclear egress, there are now numerous reports of capsid-associated pUL36 being present in the nucleus $[75,136,137]$. While pUL36 is not essential for nuclear egress of HSV-1 or PrV, a recent study suggested that a nuclear-specific isoform comprising the C-terminal region of pUL36 is recruited to PrV capsids in the nucleus and enhances 
their nuclear egress [138]. Since the nuclear-specific isoform of pUL36 lacks regions required for virion assembly, it follows that full-length pUL36 can replace the C-terminal fragment at a later stage during maturation [138]. Failure to detect the nuclear localization of pUL36 in some studies but not others may in some cases be explained by the use of antibodies targeting $\mathrm{N}$-terminal epitopes not present in the nuclear-localized C-terminal pUL36 fragment [138].

In addition to binding pUL19/VP5, pUL36 also appears to form part of the capsid vertex-specific component (CVSC, Figure 4). The CVSC is a complex containing the proteins pUL17 and pUL25 that forms over penton-proximal pUL18-pUL38 (VP23-VP19C) triplexes [139-141] (Figure 4). Assembly of the CVSC is proposed to promote nuclear egress of DNA-filled C-capsids [140-142], although its presence is not exclusive to C-capsids [135,141]. Cryo-EM studies of HSV-1 and PrV capsids have previously positioned pUL17 in the CVSC density closest to the penton vertex and pUL25 in the penton-distal density $[135,141,143,144]$. However, attempts to fit the crystal structure of a large fragment of HSV-1 pUL25 (47\% identity with PrV pUL25) into the CVSC density of PrV C-capsids were unsuccessful and it was proposed that either the folds of HSV-1 and PrV pUL25 are different, or that the conformation adopted by pUL25 differs when in virions versus in the crystalline state [135]. Recently, a high-resolution cryo-EM reconstruction of virions showed Karposi's sarcoma-associated herpesvirus (KSHV), a gammaherpesvirus, to contain a region of tegument near the penton vertices that obeyed icosahedral symmetry, analogous to the CVSC of alphaherpesviruses [145]. However, analysis of this reconstruction in the light of available tertiary and secondary structural data suggested a significantly different arrangement of the pUL17 and pUL25 homologues compared with previous alphaherpesvirus cryo-EM analyses. Specifically, the authors concluded that ORF19, the pUL25 homologue, forms the globular cap over the penton vertex while the penton-distal density is comprised of ORF32, the pUL17 homologue, plus additional density from an unidentified protein. Further, they showed that a similar arrangement of pUL25 and pUL17 would allow a good fit of a dimer of pUL25 into the previously published PrV cryo-EM maps [135,145]. The authors suggest that the elongated nature of the N-terminal segment of ORF19, homologous to a region of pUL25 not present in the crystal structure, would have confounded the interpretation of prior alphaherpesvirus cryo-EM reconstructions performed in the presence of labelled pUL25 $[135,141,143]$ and may have led to incorrect assignment of the pUL25- and pUL17-containing CVSC density [145].

Association of pUL36 with capsids in PrV infected cells is dependent on the expression of pUL25 [106], and homologues of both pUL36 and pUL25 from PrV and HSV-1 co-immunoprecipitate when transiently expressed together in cells $[70,106]$. In HSV-1, a C-terminal region within pUL36 (residues 2430-2893) is sufficient for recruitment to cytoplasmic capsids during assembly [62]. A recent study of capsids formed by HSV-1 strains lacking UL36 showed that extensive CVSC structures are formed only in the presence of pUL36 [107]. Furthermore, the pUL36 dependence of CVSCs was apparent for C-capsids purified both from the nuclear and cytoplasmic fractions of HSV-1 infected cells [107]. This is consistent with pUL36 (or a C-terminal portion thereof) binding C-capsids in the nucleus, but being replaced with full-length cytoplasmic pUL36 upon C-capsid nuclear exit, and with pUL36 forming part of the CVSC (Figure 4), occupying a position similar to that of the "unidentified" density observed in the KSHV cryo-EM reconstruction [107,145]. We anticipate that higher resolution structural characterization will provide final confirmation of the composition and arrangement of nuclear and cytoplasmic alphaherpesvirus CVSCs and the contribution of pUL36 to these structures. 


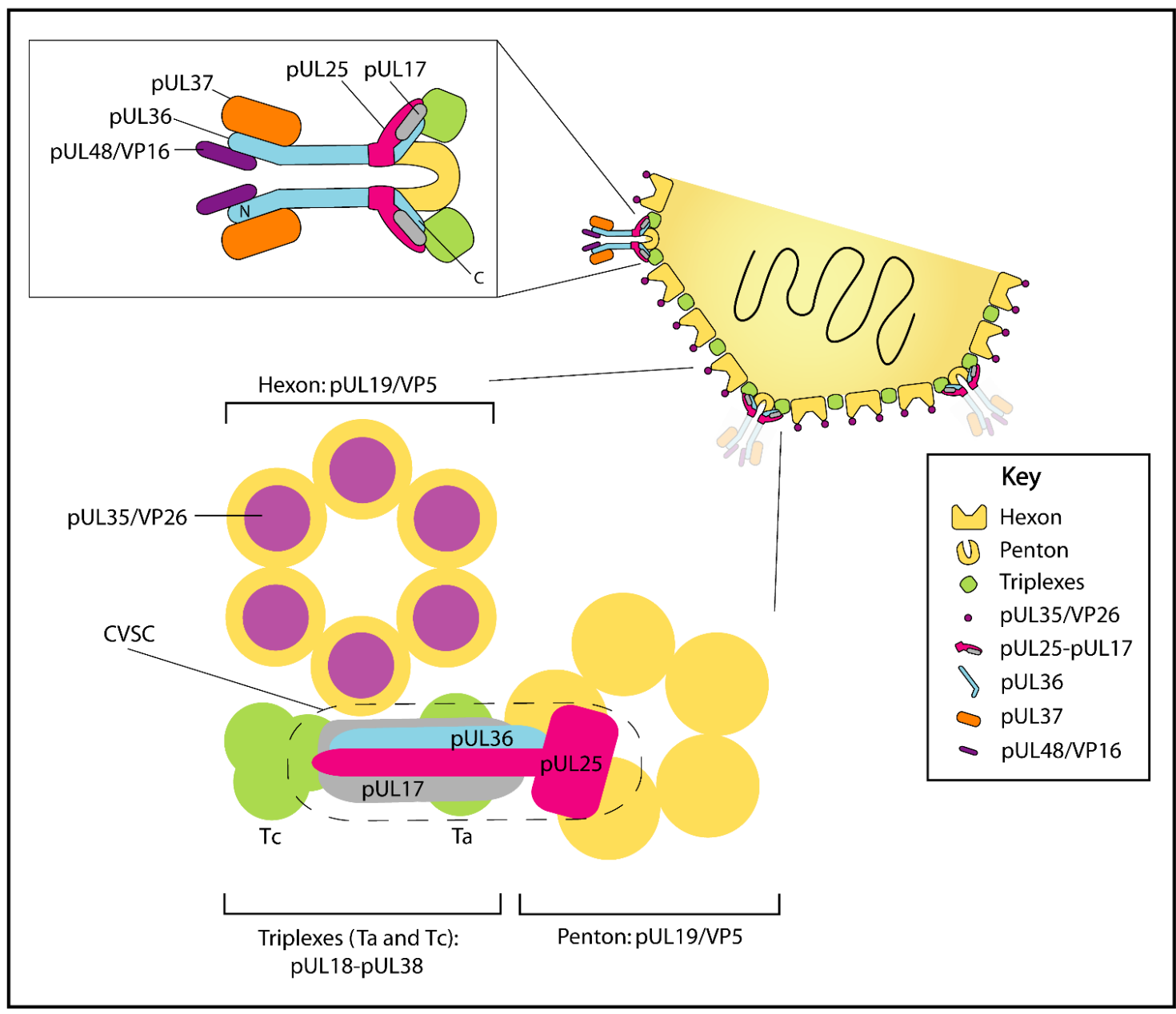

Figure 4. Protein pUL36 extends from capsid vertices and interacts with the capsid vertex-specific component (CVSC). (Top inset) The extended N-terminal region of pUL36 interacts with pUL37 and pUL48. For clarity pUL36 and pUL37 are not drawn to scale. (Bottom inset) Recent studies of HSV, PrV and KSHV $[107,135,145]$ suggest that CVSC component pUL25 lies over the penton vertex, pUL17 lies above the penton proximal pUL18-pUL38 triplex, a C-terminal region of pUL36 contributes to the CVSC density, and that pUL36 is essential for CVSC formation.

\subsection{The pUL36-pUL37 Complex Acts as a Scaffold for Tegumentation and Secondary Envelopment}

Protein pUL36 is the largest tegument protein and the N-terminal regions of pUL36 from HSV-1 and PrV interact with the second-largest conserved tegument protein, pUL37 [108]. Protein pUL37 is essential for HSV-1 replication and its deletion severely attenuates replication of $\operatorname{PrV}[132,146,147]$. The pUL37-null phenotype in HSV-1 can be partially rescued by transfecting infected cells with a C-terminal fragment of pUL37 encompassing residues 568-1123 [148]. Recruitment of pUL37 to HSV-1 capsids is dependent on pUL36 [148], and this interaction is conserved between homologues in human cytomegalovirus and KSHV, belonging to the beta- and gammaherpesvirus subfamilies, respectively [149-151]. Capsid-bound pUL36 is proposed to extend from capsid vertices and, together with pUL37, to form the filamentous structures that have been observed by cryo-EM of capsids lacking tegument proteins except pUL36 and pUL37 [22,24]. In support of this, a recent crystal structure of a central portion of pUL36 (residues 1600-1733) shows this region to possess an elongated alpha-helical conformation and sedimentation velocity analysis of a fragment encompassing residues 760-1733 is consistent with an elongated structure [152]. A dimer of the pUL36-pUL37 homologues from human cytomegalovirus (pUL48-pUL47) also appears to form a filamentous structure [153]. 
Unlike most other tegument proteins, pUL36 and pUL37 are incorporated into virions with a fixed stoichiometry and overexpression of pUL37 in infected cells did not increase its incorporation into virions $[105,154,155]$. The stoichiometry of pUL37 is also maintained in L-particles, suggesting that it is determined by something intrinsic to the tegument structure or viral membrane in the absence of capsids [154]. Interestingly, pUL36 and GFP-tagged pUL37 from HSV-1 have been shown to co-localize with Golgi markers at a juxtanuclear compartment independently of capsids [156]. Precisely how these proteins are recruited to these membranes is unknown, but recruitment of pUL37 depended on pUL36 expression [156]. Direct or indirect interactions with outer tegument proteins, for example pUL36 with pUL48 in HSV-1 [74,111], or with glycoprotein tails may be involved. Recently, immunoprecipitation experiments from infected cells have shown HSV-1 pUL37 to interact with gK and its membrane-associated binding partner pUL20 [113]. The gK-pUL20 complex has been implicated in secondary envelopment and the release of virions from infected cells [157-159]. HSV-1 and PrV lacking pUL20, and HSV-1 lacking gK, accumulate enveloped and non-enveloped capsids in the cytoplasm [160-165]. It has been proposed that the interaction between pUL37 and the gK-pUL20 complex may contribute to secondary envelopment by linking the pUL36-pUL37 complex with the viral envelope [113]. An interaction between HSV-1 pUL37 and the capsid hexon-cap protein pUL35/VP26 has been detected by yeast two-hybrid screen and may have a minor role in recruiting pUL37 to capsids [72,112].

The exposure of pUL36 and pUL37 on the surface of capsids may facilitate motor protein recruitment for microtubule-based transport of capsids to secondary envelopment sites (reviewed [7,48]). In PrV and HSV-1, both pUL36 and pUL37 have been implicated in microtubule-based transport during egress $[57,61,166,167]$. Since pUL36 and pUL37 are also linked to retrograde capsid transport during entry there must be an additional factor or condition that determines the overall direction of capsid transport. It is currently unknown how the directional transport of capsids is regulated in cells, but it is likely that a component of the virus particle modulates the switching between dynein and kinesin directed transport [51]. To this end, post-translational modification of pUL36 or the recruitment of other viral tegument proteins to the motor complex have been predicted to play a role [7]. A crystal structure of the N-terminal half of pUL37 from PrV has recently been determined, showing this region to be organized into three domains. One of these domains shares structural similarity with the CATCHR family of multi-subunit tethering complexes [168], complexes that modulate host-cell vesicle trafficking by tethering membranes destined for fusion [169], and the authors postulate that pUL37 may mimic this function and tether $\operatorname{PrV}$ capsids to membranes during secondary envelopment.

\section{3. pUL46, pUL47, pUL48 and pUL49: Central Organizers of Tegument}

The pUL46, pUL47, pUL48 and pUL49 proteins act as central organizers of tegument by forming interactions with inner and outer tegument proteins and viral glycoproteins. These are the most abundant tegument proteins in the mature virion and are thought to be unique to the alphaherpesvirus subfamily $[16,17,71]$, although a recent crystal structure of a C-terminal domain of pUL49/VP22 showed unexpected structural homology with ORF52 from murid herpesvirus 4, a gammaherpesvirus [170]. Of the four proteins only pUL48 is considered to be essential for HSV-1 replication in tissue culture $[117,127,171-174]$. In $\operatorname{PrV}$, deletions of each of these four proteins individually can be tolerated [93,175-177]. Furthermore, simultaneous deletion of UL46, UL47, UL48 and UL49 in PrV does not block virion assembly in tissue culture but virus replication is strongly attenuated [178]. Tolerance to deletion of these proteins, as with many other tegument proteins, possibly arises from the redundancy in protein:protein interactions that form the tegument and through compensatory increases in the incorporation of other tegument proteins. For example, deletion of UL47 or UL49 in PrV leads to a specific increase in the packaging of lower molecular weight isoforms of pUL48 [93], and packaging of HSV-1 pUL46 is enhanced in the absence of pUL47 [173]. 
Secondary envelopment of HSV-1 capsids is abolished in the absence of pUL48 and is strongly suppressed but not abolished in PrV lacking UL48 [171,172,176]. The pUL48 protein of HSV-1 has been shown to interact with the essential inner tegument protein pUL36 [74,110,111], outer tegument proteins pUL41, pUL46 and pUL49 [74,114,119,123], and the cytoplasmic tail of gH in vitro [124-126]. A cross-linking experiment also highlighted glycoproteins $\mathrm{gB}$ and $\mathrm{gD}$ as potential pUL48 binding partners [126]. The requirement for pUL48 in HSV-1 secondary envelopment may be attributed to its ability to form numerous interactions that bridge the capsid and virus envelope. In PrV the deletion of UL48 results in the production of large quantities of L-particles that contain pUL46, pUL47 and pUL49, but not pUL36 and pUL37, suggesting that pUL48 could provide a key link between inner and outer tegument [176]. However, while pUL48 interacts with pUL36 and could thus link membranes and capsids, packaging of pUL48 into HSV-1 virions is not decreased when this interaction is abolished [74,110,111].

The pUL49 protein has also been proposed to contribute to secondary envelopment through the formation of a tegument-glycoprotein complex comprising pUL49, gE-gI, gM and ICP0, whereby the $\mathrm{C}$ terminus of pUL49 bridges the cytoplasmic tails of $\mathrm{gE}$ and $\mathrm{gM}$ and the $\mathrm{N}$ terminus recruits ICP0 [129]. In HSV-1 infected cells, pUL49 is recruited to TGN membranes though interactions with $\mathrm{gE}$ and $\mathrm{gM}[128,129]$; packaging of pUL49 into virions is unaffected by deletion of either glycoprotein individually but a double deletion virus fails to incorporate pUL49 [129]. Glycoprotein I (gI) is recruited to the complex through an interaction with gE; mutants lacking pUL49 incorporate less gE-gI and ICP0 is also absent [127,179]. pUL49 of PrV has also been shown to interact with gE and gM by yeast two-hybrid screen [130]. Triple mutant viruses lacking gE-gI and gD (HSV-1) or gM (PrV) accumulate unenveloped cytoplasmic capsids, suggesting that these proteins play important but redundant roles in secondary envelopment [180,181]. Additionally, a tripartite complex comprising pUL49-pUL48-pUL41 has been proposed, which may promote secondary envelopment through the pUL49-gE-gI complex (reviewed [12]). However, despite the central role of pUL49 in these complexes the deletion of UL49 in both HSV-1 and PrV does not have a significant effect on virus assembly and a PrV UL49 deletion virus does not exhibit an obvious defect in secondary envelopment $[93,127,174]$. Interestingly, HSV-1 pUL49 has also been shown recently to co-localize with the N-terminal domain (residues 1-155) of pUL16 in the absence of other viral proteins, and pUL49 is very poorly incorporated into pUL16-null virions [104]. However, the contribution this interaction makes to HSV virion maturation is currently unclear. It is also worth noting that deletion of UL49 from HSV-1 causes mutation of UL41 when viruses are propagated in non-complementing cells, presumably due to pUL49 being important for controlling the activity of pUL41/vhs [182-184]. Caution may therefore be needed when interpreting the impact of pUL49 removal as, depending on how the UL49 deletion viruses have been propagated, some of the observed phenotypes may actually arise from changes in pUL41/vhs activity.

Little is currently known about the precise contributions of pUL46 and pUL47 to virus assembly. A PrV UL47 deletion mutant accumulates aggregates of partially-tegumented capsids in the cytoplasm and exhibits a 10-fold reduction in viral titer, but no assembly defect was apparent for the UL46 deletion mutant in this study [175]. Mean survival times of mice infected with a PrV UL46 deletion virus were similar to those of the wild-type virus, while survival times increased for mice infected with UL47-, UL11- or UL48-deleted PrV viruses [185]. Yeast two-hybrid interaction screens have identified several capsid (pUL19/VP5, pUL18/VP23, pUL38/VP19C, pUL25), tegument (pUL21, pUL37, pUL48, pUS3, pUS10) and membrane (pUL45, gK, gM) proteins as potential binding partners for pUL46 $[72,74,116]$, suggesting that this protein is able to bridge the capsid to the outer membrane. Interactions between pUL46 and pUL21, pUS3, pUS10 and gM were also identified by mass spectrometry following immunoaffinity purification from cells infected with a HSV-1 GFP-pUL46 virus, as were interactions with ICP0 and a number of host-cell protein kinases [115]. In HSV-2 infected cells pUL46 has been shown to co-localize and co-purify with pUL48 [114] and this interaction has also been confirmed for HSV-1 by in vitro GST pull-down experiments [74]. 
Similarly, pUL47 forms numerous interactions with other tegument proteins (pUL14, pUL21, pUL48, pUL49, pUS11) in yeast two-hybrid interaction screens [116]. Immunoprecipitation of pUL47 with pUL48 from HSV infected cells has been reported [110], and the absence of pUL47 during infection diminished pUL48-mediated reporter gene transcription [117]. The capsid protein pUL17 has also been shown to co-immunoprecipitate and co-localize with pUL47 from HSV-1 infected cells and may provide an additional link between the capsid and tegument [118]. Despite the many pUL46 and pUL47 interaction partners identified by yeast two-hybrid or proteomic studies only a few have been validated by in vitro or cell-based experiments. Further investigation is therefore required to ascertain the precise contributions of pUL46 and pUL47 to virus assembly.

\section{4. pUL11, pUL16 and pUL21 form a Tripartite Complex}

In addition to the glycoproteins embedded within the envelope, HSV-1 virions contain several membrane-associated tegument proteins [186]. One such protein, HSV-1 pUL11, associates with Golgi membranes in infected cells via myristoyl and palmitoyl anchors, the latter modification determining membrane specificity [187-189]. Partitioning of HSV-2 pUL11 into lipid rafts has been shown to require both acyl modifications [190]. HSV-1 pUL11 membrane association may also be facilitated though an interaction of this protein with the cytoplasmic tail of $\mathrm{gE}$, which has been demonstrated in vitro [99-101]. Virion packaging of pUL11 is substantially reduced upon deletion of the $\mathrm{gE}$ cytoplasmic tail, and a reciprocal defect in $\mathrm{gE}$ packaging is also observed upon deletion of UL11 [100]. Although UL11 is not essential for viral replication, deletion of this gene or its homologues from HSV-1, PrV or human cytomegalovirus leads to defective secondary envelopment and an accumulation of cytoplasmic capsids to varying degrees [191-196]. Interestingly, HSV-1 pUL11 expressed without acyl modifications partially recovered the growth defects of a UL11 deletion virus, demonstrating that some pUL11 function is maintained when the protein is not membrane-bound [197].

The tegument protein pUL16 has been shown to interact with pUL11 [96-98] and gE [101,103] in HSV-1 and with pUL21 in both HSV-1 and PrV [98,101,102]. Both pUL16 and pUL21 are simultaneously pulled-down by GST-pUL11 from lysates of cells infected with wild-type HSV-1, while GST-pUL11 fails to pull-down pUL21 from lysates infected with a UL16 deletion virus [98]. It is also likely that GST-pUL11 of PrV is able to pull-down pUL16 and pUL21 homologues from PrV-infected lysates [98]. Furthermore, packaging of pUL11 and pUL21 is severely reduced in a virus lacking UL16 and the amount of pUL16 incorporated into virions is drastically reduced in the absence of either pUL11 or pUL21 [104,198]. Together these findings provide support for the formation of a tripartite complex with pUL16 at the centre linking pUL11 and pUL21.

GST pull-downs experiments have demonstrated a direct interaction between HSV-1 pUL16 and $\mathrm{gE}$ in vitro [103]. However, transfection experiments showed that co-localization between pUL16 and co-transfected gE or pUL11 in the absence of virus infection is poor [101,103]. Truncation experiments revealed that the $\mathrm{C}$ terminus of pUL16 negatively regulates its interaction with $\mathrm{gE}$ and pUL11: removing the C-terminal region (residues 156-373) enhanced the ability of pUL16 to co-localize with pUL11 or gE in co-transfection experiments [103,199]. Co-transfection of pUL16, pUL11 and pUL21 together leads to the efficient co-localization of pUL16 with pUL11, suggesting that pUL21 can relieve the repression of pUL11 binding that is conferred by the pUL16 C-terminal region [101]. Further co-transfection studies show the interaction between pUL16 and gE to be substantially enhanced in the presence of pUL11 but less so in the presence of pUL21 [101]. Therefore, it has been proposed that pUL11-pUL16-pUL21 complex is able to interact with membranes by assembling on the cytoplasmic tail of gE via pUL11 and via pUL16, with direct binding of pUL11 to gE promoting the gE-pUL16 interaction [101] (Figure 5). An alternative hypothesis is that pUL16 acts as a virus-encoded chaperone, promoting the correct folding of pUL11, pUL49 and gE rather than forming molecular interactions to bridge them directly [104,199]. 


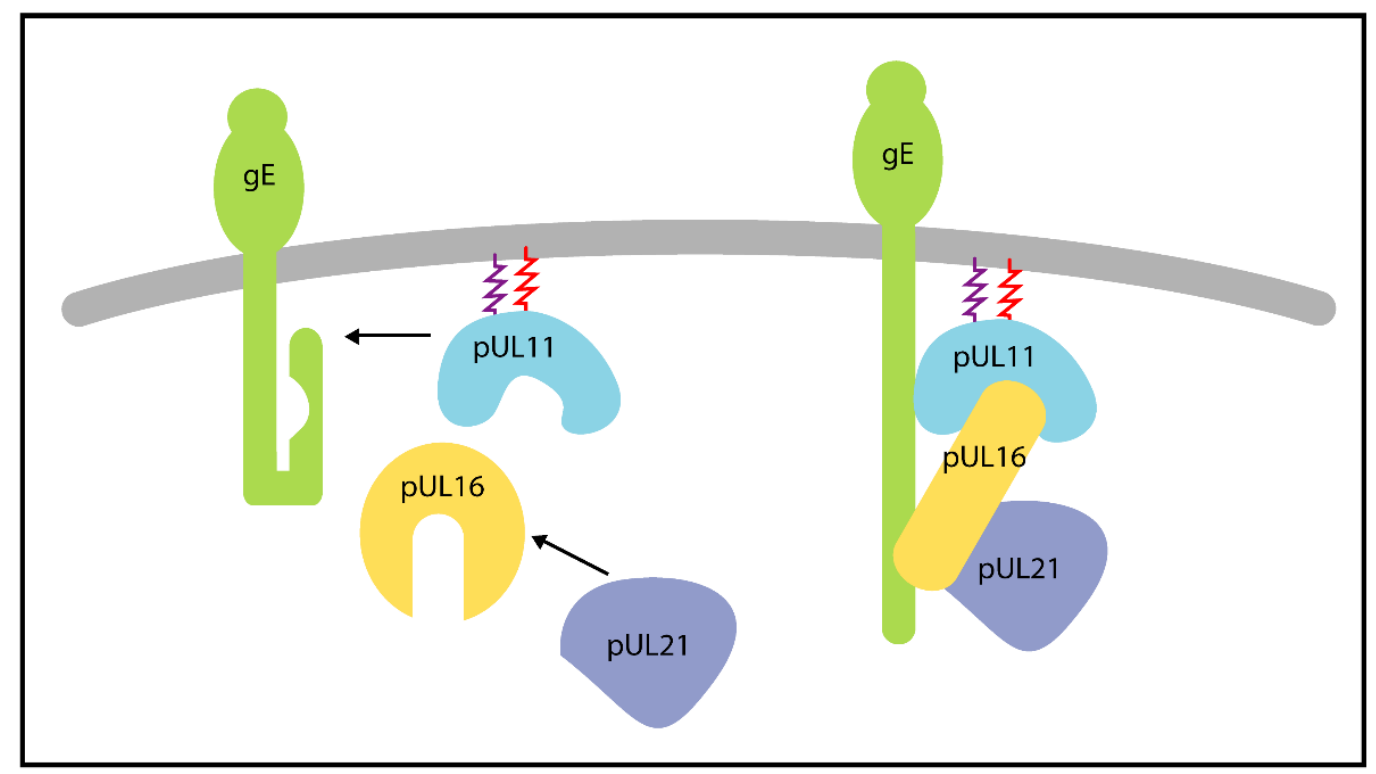

Figure 5. Proteins pUL11, pUL16 and pUL21 may form a tripartite complex that binds gE. The C-terminal domain of pUL16 inhibits its ability to co-localise with pUL11 and gE, co-localization of pUL16 with pUL11 is enhanced in the presence of pUL21, and the presence of pUL11 promotes co-localization of pUL16 and gE [101]. An alternative model is that pUL16 acts as a molecular chaperone, promoting the correct folding of pUL11, pUL21 and/or gE.

In HSV-1 infected cells pUL16 has been shown to associate with capsids in the cytoplasm independently of pUL36 and pUL37 [198,200]. PrV pUL21 is also reportedly capsid associated [201]. These observations led to the proposal of a simple hypothesis whereby the interaction between membrane-associated pUL11 and capsid-associated pUL16 (and pUL21) could provide a physical link between the capsid and tegument to promote secondary envelopment [12]. If this were the case we might expect a similar phenotype for the deletion of UL16 as is observed upon deletion of UL11. However, these viruses are phenotypically distinct: the HSV-1 UL16 deletion virus forms clusters of membrane-associated capsids in the cytoplasm and has an increased propensity to form multi-capsid virions [104], whereas deletion of UL11 from HSV-1 or PrV causes the cytoplasmic accumulation of non-enveloped capsids in association with electron-dense tegument-derived material [191,192,196,202]. Further experiments are thus required determine how these proteins promote correct virion assembly and probe whether pUL16 forms a stable bridge between pUL11 and pUL21 or acts as a virally-encoded chaperone.

\section{5. pUL51-pUL7 Complex May Promote Secondary Envelopment}

Another membrane-associated tegument protein implicated in secondary envelopment is pUL51. HSV-1 and PrV UL51 mutant viruses exhibit a reduction in viral titer compared to wild type and accumulate non-enveloped capsids in the cytoplasm [203,204]. HSV-1 pUL51 localizes at the Golgi in transfected cells through an N-terminal palmitoyl modification [205]. The localization differs in infected cells, with pUL51 clustering at a juxtanuclear assembly compartment and at the perinuclear compartment [205]. Recently HSV-1 pUL51 has been reported to interact with a second tegument protein, pUL7, which also localizes to a juxtanuclear compartment during infection $[95,206]$. In infected and transfected cells pUL7, pUL51 and gE partially co-localize on cytoplasmic membranes and this co-localization is lost in the absence of pUL51, suggesting that membrane localization of pUL7 is specifically mediated by the pUL51 protein [95]. Efficient packaging of pUL7 into virions was also shown to be dependent on pUL51 [95]. Furthermore, the phenotype for UL7-null PrV is similar to that described for the pUL51-deficient PrV and HSV-1 viruses [206,207]. The HSV-1 UL7 
deletion virus is also defective for cellular egress, but it is unknown whether this is due to impaired secondary envelopment [208]. Taken together these findings suggest that pUL7 and pUL51 function as a complex during viral maturation that promotes secondary envelopment, although how they act in concert to achieve this is currently unclear.

\section{Secondary Envelopment and Viral Egress}

\subsection{Secondary Envelopment Occurs at Post-Golgi Membranes}

There is little doubt that alphaherpesviruses acquire their final lipid envelope from post-Golgi membrane compartments, although the precise identity of the cytoplasmic compartment(s) where secondary envelopment occurs has been the topic of much recent debate. Many studies have provided evidence for the TGN being the site of HSV-1, PrV and VZV secondary envelopment, primarily through analysis of cellular markers of the TGN and treatments that disrupt TGN function $[84,209,210]$. More recently, evidence for endosomal membranes being the sites of HSV-1 secondary envelopment has been published, where endocytic tracers were localized to sites of secondary envelopment and the early endosome regulator Rab5 was shown to be important for HSV-1 envelopment [86]. Classically the TGN is considered as a major sorting organelle within the secretory pathway that directs newly synthesized proteins, after appropriate processing and transit through the Golgi, to various cellular destinations including endosomes, lysosomes and the plasma membrane [211,212]. However, the TGN also receives proteins from the endocytic pathway, including proteins internalized from the plasma membrane, and so this organelle can also be considered part of the endosomal system [213,214]. Membrane traffic within the secretory and endocytic pathways comprises of a network of highly dynamic and interconnected compartments that rapidly transport proteins between each other using vesicle carriers and/or direct fusion, and so the content of different compartments can mix in various locations. Cellular membrane proteins that are used as markers of the TGN and other post-Golgi compartments predominantly localize to these compartments at steady state, by definition, but often do so in a highly dynamic fashion involving traffic to and from endosomal compartments and the plasma membrane in normal cells. Therefore, data demonstrating the localization of TGN markers and endocytic tracers to HSV-1 secondary envelopment sites are not necessarily contradictory given the intimate association of the TGN with the endocytic pathway. One of the problems faced when attempting to define membrane compartment identity in infected cells is that HSV-1 is known to dramatically re-organize the cytoskeleton and the secretory and endocytic pathways $[215,216]$. Therefore, assessing the origin of secondary envelopment membranes, which are likely to be quite heterogeneous, is not straightforward. These issues may be clarified in the future by examining the dynamics of HSV-1 envelope protein transport in parallel with cellular "compartment-marker" membrane proteins in infected cells, and by probing the specific involvement of different endocytic and exocytic vesicle transport pathways in HSV-1 secondary envelopment.

\subsection{Trafficking of Glycoproteins to Sites of Secondary Envelopment}

Whatever the precise origin of the membranes that make up the secondary envelopment compartments, all the viral membrane proteins destined to become part of the mature virion must be trafficked to these sites. Given the varying expression kinetics of the 16 different virally encoded membrane proteins that are thought to be in the mature virion $(\mathrm{gB}, \mathrm{gC}, \mathrm{gD}, \mathrm{gE}, \mathrm{gG}, \mathrm{gH}, \mathrm{gI}, \mathrm{gJ}, \mathrm{gK}, \mathrm{gM}$, gN, pUL20, pUL43, pUL45, pUL56 and pUS9), it seems likely that many of these membrane proteins will be trafficked to secondary envelopment compartments either independently, or in subcomplexes, rather than as a fully-formed cluster of all 16 different membrane proteins in the correct stoichiometry. Many of these viral envelope proteins contain consensus sequences within their cytoplasmic domains that would be predicted to mediate their subcellular localization via interactions with cellular protein sorting machinery. This has most clearly been demonstrated for viral membrane proteins such as $\mathrm{gB}$ and $\mathrm{gE}$, which contain tyrosine-based motifs that are known to interact with clathrin adaptors 
and are important for the endocytosis and intracellular localization of these glycoproteins [217-220]. However, several viral membrane proteins do not contain any predicted trafficking motifs and thus rely on other viral proteins for their correct localization and incorporation into virions. For example, in HSV-1 it appears that localization of the gE-gI heterodimer to the TGN relies on trafficking motifs within the cytoplasmic domain of gE [221], and the ER-exit and TGN localization of gK and pUL20 has been shown to be interdependent [165]. It has also been shown that the essential HSV-1 entry proteins gD and gH-gL rely on the trafficking activity of gM and/or gK-pUL20 to mediate their endocytosis and localization to sites of secondary envelopment $[163,222,223]$. While the molecular details of how many of the viral envelope proteins are localized to secondary envelopment compartments are unclear, it seems likely that a combination of different endocytic and/or other vesicle transport pathways bring these membrane proteins together in the same location. Presumably, the still poorly-defined network of protein:protein interactions linking envelope proteins with each other and the underlying tegument will then provide sufficient structure and stability to allow the budding/wrapping process to occur, normally around a capsid to form virions, but also occurring in the absence of capsids in the case of L-particles.

\subsection{The End of Secondary Envelopment: Membrane Scission Mediated by the Host-Cell ESCRT Pathway}

The final stage in herpesvirus virion assembly can be considered as the membrane scission event that separates the newly formed virus from the surrounding host-cell membrane, giving rise to a fully formed virion contained within the lumen of a large transport vesicle. Topologically, this is the same process that is required for the final stages of budding for any enveloped virus, whether such a virus buds directly through the plasma membrane (such as HIV) or into the lumen of a cytoplasmic organelle (such as herpesviruses). Many enveloped viruses have been shown to utilize the membrane scission activity of the cellular endosomal sorting complex required for transport (ESCRT) machinery for this crucial step in their assembly [224]. Herpesviruses appear to be no exception: ESCRT function is important for the assembly of members of all three subfamilies of herpesvirures as has been demonstrated for HSV-1 and PrV (alphaherpesviruses) [225-228], human cytomegalovirus (betaherpesvirus) [229] and Epstein-Barr virus (gammaherpesvirus) [230], although in the case of Epstein-Barr virus the main defect observed in the absence of ESCRT function was in nuclear egress. The ESCRT machinery is a set of multiprotein complexes that are normally involved in the formation of intraluminal vesicles by an inward budding process into the lumen of multivesicular bodies, as well as membrane scission during the abscission event that separates cells at the end of cytokinesis [231,232]. It is important to note that a requirement for the activity of the ESCRT machinery during herpesvirus secondary envelopment does not help define the source of membrane for cytoplasmic assembly compartments. The ESCRT machinery is relatively mobile and can be recruited to multiple cellular membranes under different conditions, and so the involvement of the ESCRT machinery in itself does not allow any firm conclusions to be drawn on sites of HSV-1 envelopment. Currently it is unclear how herpesviruses recruit and regulate the ESCRT machinery at sites of their assembly. By analogy with other viruses that are known to recruit ESCRT complexes via their matrix proteins (see Table S1 in [224]), tegument protein(s) appear the most likely candidates to directly or indirectly interact with ESCRT proteins. Indeed HSV-1 pUL36 has recently been shown to interact with TSG101, a component of the ESCRT-I complex, although the importance of this interaction for secondary envelopment was not investigated in this study [233]. However, given the complexity of the tegument, as well as the redundant nature of protein:protein interactions within the tegument, recruitment of the ESCRT machinery to sites of secondary envelopment seems likely to be mediated by multiple viral proteins.

\subsection{Trafficking of Assembled Virions to the Plasma Membrane}

Currently there is little understanding of how mature herpesvirus virions are released from cells following secondary envelopment. Undoubtedly these viruses utilise proteins involved in 
the host cell secretory pathway to facilitate egress at the plasma membrane. In particular, Rab3A, Rab6A, Rab8a, Rab11a, GAP-43, kinesin-1 and SNAP-25 have been shown to traffic with viral tegument and glycoproteins to egress sites for HSV-1 and PrV [234,235]. Amyloid precursor protein, an integral membrane protein, co-purifies with intracellular HSV-1 viral particles and has been shown to enhance trafficking of particles with GFP-labelled pUL35/VP26 during egress, possibly by recruiting kinesin-1 [236]. The cellular membrane traffic mediators protein kinase $\mathrm{D}$, which regulates the exit of secretory cargo from the TGN, and myosin Va, which transports vesicles through the cortical actin network, have also been shown to play a role in the egress of HSV-1 [237,238]. Furthermore, knockdown of Rab6A, Rab10, Rab13 and Annexin1 in a genome-wide siRNA screen was detrimental to HSV-1 replication to varying degrees [239]. Interestingly, knockdown of Rab6A, which is involved in Golgi to plasma membrane transport, inhibits capsid envelopment, further supporting the hypothesis that glycoprotein trafficking to the plasma membrane is a prerequisite for viral maturation $[86,240]$. Viral glycoproteins and membrane-associated tegument proteins are candidates for recruiting host-cell proteins involved in the secretory pathway since they may be present on the surface of viral transport vesicles. However, as yet there is no understanding of the level of partitioning of viral proteins between the viral envelope and the surrounding transport vesicle membrane.

\section{Perspectives and Open Questions}

As detailed above, recent advances in the field of alphaherpesvirus assembly have illuminated many conserved interactions between proteins that mediate tegument assembly and secondary envelopment. However, despite having mapped interactions between tegument proteins, a functional understanding of how these proteins act together to promote virion assembly remains elusive. The role that host-cell binding partners of tegument proteins play in the process of virion assembly also remain enigmatic. Some outstanding questions of particular interest are as follows:

- What is the precise molecular composition of the CVSC and how does it promote nuclear egress of DNA-loaded capsids?

- What is the protein composition of the PVAT and when does it associate with capsids?

- Are tegument sub-complexes like pUL7-pUL51 and pUL11-pUL16-pUL21 pre-formed in infected cells or do these proteins associate only when tegument is condensing on capsids?

- Do some tegument proteins have non-structural roles in tegument assembly, as hypothesised for the putative virus-encoded protein chaperone pUL16?

- How are the viral glycoproteins transported to and organised within the secondary envelopment compartments?

- What is the source/identity of the cellular membrane used for secondary envelopment and are viral/cellular proteins actively partitioned into virions or virion transport vesicles?

- What are the molecular links between tegument and the cellular ESCRT machinery that promote secondary envelopment?

- How is tegument asymmetry generated and what is the role of PVAT in defining such asymmetry?

- How many tegument proteins act to modulate the host-cell environment immediately following virus infection, before the initiation of viral protein expression?

A molecular understanding of the interactions that mediate alphaherpesvirus assembly should prove insightful for the study of all herpesviruses, illuminating conserved, essential molecular interactions that may be targeted in the design of novel therapeutics and expanding our knowledge of host cell post-Golgi membrane trafficking pathways.

Acknowledgments: DJO is supported by the John Lucas Walker Studentship. HSV-1 research in the laboratory of CMC is supported by the Leverhulme Trust (Grant RPG-2012-793) and the Biotechnology and Biological Sciences 
Research Council (Grant BB/M021424/1). SCG is a Sir Henry Dale Fellow jointly funded by the Wellcome Trust and the Royal Society (Grant Number 098406/Z/12/Z).

Conflicts of Interest: The authors declare no conflict of interest.

\section{References}

1. Mocarski, E.S., Jr. Comparative analysis of herpesvirus-common proteins. In Human Herpesviruses: Biology, Therapy, and Immunoprophylaxis; Arvin, A., Campadelli-Fiume, G., Mocarski, E., Moore, P.S., Roizman, B., Whitley, R., Yamanishi, K., Eds.; Cambridge University Press: Cambridge, UK, 2007; pp. 44-58.

2. Davison, A.J.; Eberle, R.; Ehlers, B.; Hayward, G.S.; McGeoch, D.J.; Minson, A.C.; Pellett, P.E.; Roizman, B.; Studdert, M.J.; Thiry, E. The order Herpesvirales. Arch. Virol. 2009, 154, 171-177. [CrossRef] [PubMed]

3. McGeoch, D.J.; Gatherer, D. Integrating reptilian herpesviruses into the family herpesviridae. J. Virol. 2005, 79, 725-731. [CrossRef] [PubMed]

4. Pomeranz, L.E.; Reynolds, A.E.; Hengartner, C.J. Molecular biology of pseudorabies virus: Impact on neurovirology and veterinary medicine. Microbiol. Mol. Biol. Rev. 2005, 69, 462-500. [CrossRef] [PubMed]

5. Smith, G. Herpesvirus transport to the nervous system and back again. Annu. Rev. Microbiol. 2012, 66, 153-176. [CrossRef] [PubMed]

6. Nicoll, M.P.; Proença, J.T.; Efstathiou, S. The molecular basis of herpes simplex virus latency. FEMS Microbiol. Rev. 2012, 36, 684-705. [CrossRef] [PubMed]

7. Kramer, T.; Enquist, L.W. Directional spread of alphaherpesviruses in the nervous system. Viruses 2013, 5, 678-707. [CrossRef] [PubMed]

8. Mettenleiter, T.C. Herpesvirus assembly and egress. J. Virol. 2002, 76, 1537-1547. [CrossRef] [PubMed]

9. Newcomb, W.W.; Juhas, R.M.; Thomsen, D.R.; Homa, F.L.; Burch, A.D.; Weller, S.K.; Brown, J.C. The UL6 gene product forms the portal for entry of DNA into the herpes simplex virus capsid. J. Virol. 2001, 75, 10923-10932. [CrossRef] [PubMed]

10. Zhou, Z.H.; Dougherty, M.; Jakana, J.; He, J.; Rixon, F.J.; Chiu, W. Seeing the herpesvirus capsid at 8.5 A. Science 2000, 288, 877-880. [CrossRef] [PubMed]

11. Newcomb, W.W.; Booy, F.P.; Brown, J.C. Uncoating the herpes simplex virus genome. J. Mol. Biol. 2007, 370, 633-642. [CrossRef] [PubMed]

12. Johnson, D.C.; Baines, J.D. Herpesviruses remodel host membranes for virus egress. Nat. Rev. Microbiol. 2011, 9, 382-394. [CrossRef] [PubMed]

13. Mettenleiter, T.C.; Klupp, B.G.; Granzow, H. Herpesvirus assembly: An update. Virus Res. 2009, 143, 222-234. [CrossRef] [PubMed]

14. Zeev-Ben-Mordehai, T.; Hagen, C.; Grünewald, K. A cool hybrid approach to the herpesvirus "life" cycle. Curr. Opin. Virol. 2014, 5, 42-49. [CrossRef] [PubMed]

15. Mettenleiter, T.C.; Müller, F.; Granzow, H.; Klupp, B.G. The way out: What we know and do not know about herpesvirus nuclear egress. Cell. Microbiol. 2013, 15, 170-178. [CrossRef] [PubMed]

16. Loret, S.; Guay, G.; Lippé, R. Comprehensive characterization of extracellular herpes simplex virus type 1 virions. J. Virol. 2008, 82, 8605-8618. [CrossRef] [PubMed]

17. Newcomb, W.W.; Jones, L.M.; Dee, A.; Chaudhry, F.; Brown, J.C. Role of a reducing environment in disassembly of the herpesvirus tegument. Virology 2012, 431, 71-79. [CrossRef] [PubMed]

18. Alemañ, N.; Quiroga, M.I.; López-Peña, M.; Vázquez, S.; Guerrero, F.H.; Nieto, J.M. L-particle production during primary replication of pseudorabies virus in the nasal mucosa of swine. J. Virol. 2003, 77, 5657-5667. [CrossRef] [PubMed]

19. McLauchlan, J.; Rixon, F.J. Characterization of enveloped tegument structures (L particles) produced by alphaherpesviruses: Integrity of the tegument does not depend on the presence of capsid or envelope. J. Gen. Virol. 1992, 73, 269-276. [CrossRef] [PubMed]

20. Radtke, K.; Kieneke, D.; Wolfstein, A.; Michael, K.; Steffen, W.; Scholz, T.; Karger, A.; Sodeik, B. Plus- and minus-end directed microtubule motors bind simultaneously to herpes simplex virus capsids using different inner tegument structures. PLoS Pathog. 2010, 6, e1000991. [CrossRef] [PubMed]

21. Wolfstein, A.; Nagel, C.H.; Radtke, K.; Döhner, K.; Allan, V.J.; Sodeik, B. The inner tegument promotes herpes simplex virus capsid motility along microtubules in vitro. Traffic 2006, 7, 227-237. [CrossRef] [PubMed] 
22. Laine, R.F.; Albecka, A.; van de Linde, S.; Rees, E.J.; Crump, C.M.; Kaminski, C.F. Structural analysis of herpes simplex virus by optical super-resolution imaging. Nat. Commun. 2015, 6, 5980. [CrossRef] [PubMed]

23. Grünewald, K.; Desai, P.; Winkler, D.C.; Heymann, J.B.; Belnap, D.M.; Baumeister, W.; Steven, A.C. Three-dimensional structure of herpes simplex virus from cryo-electron tomography. Science 2003, 302, 1396-1398. [CrossRef] [PubMed]

24. Newcomb, W.W.; Brown, J.C. Structure and capsid association of the herpesvirus large tegument protein UL36. J. Virol. 2010, 84, 9408-9414. [CrossRef] [PubMed]

25. Zhou, Z.H.; Chen, D.H.; Jakana, J.; Rixon, F.J.; Chiu, W. Visualization of tegument-capsid interactions and DNA in intact herpes simplex virus type 1 virions. J. Virol. 1999, 73, 3210-3218. [PubMed]

26. Bohannon, K.P.; Jun, Y.; Gross, S.P.; Smith, G.A. Differential protein partitioning within the herpesvirus tegument and envelope underlies a complex and variable virion architecture. Proc. Natl. Acad. Sci. USA 2013, 110, E1613-1620. [CrossRef] [PubMed]

27. Maurer, U.E.; Sodeik, B.; Grünewald, K. Native 3D intermediates of membrane fusion in herpes simplex virus 1 entry. Proc. Natl. Acad. Sci. USA 2008, 105, 10559-10564. [CrossRef] [PubMed]

28. Howard, A.J.; Sherman, D.M.; Visalli, M.A.; Burnside, D.M.; Visalli, R.J. The varicella-zoster virus ORF54 gene product encodes the capsid portal protein, pORF54. Virus Res. 2012, 167, 102-105. [CrossRef] [PubMed]

29. Schmid, M.F.; Hecksel, C.W.; Rochat, R.H.; Bhella, D.; Chiu, W.; Rixon, F.J. A tail-like assembly at the portal vertex in intact herpes simplex type-1 virions. PLoS Pathog. 2012, 8, e1002961. [CrossRef] [PubMed]

30. Campbell, M.E.; Palfreyman, J.W.; Preston, C.M. Identification of herpes simplex virus DNA sequences which encode a trans-acting polypeptide responsible for stimulation of immediate early transcription. $J$. Mol. Biol. 1984, 180, 1-19. [CrossRef]

31. Herr, W. The herpes simplex virus VP16-induced complex: Mechanisms of combinatorial transcriptional regulation. Cold Spring Harbor Symp. Quant. Biol. 1998, 63, 599-608. [CrossRef] [PubMed]

32. Stern, S.; Tanaka, M.; Herr, W. The Oct-1 homoeodomain directs formation of a multiprotein-DNA complex with the HSV transactivator VP16. Nature 1989, 341, 624-630. [CrossRef] [PubMed]

33. Wysocka, J.; Herr, W. The herpes simplex virus VP16-induced complex: The makings of a regulatory switch. Trends Biochem. Sci. 2003, 28, 294-304. [CrossRef]

34. Moriuchi, H.; Moriuchi, M.; Cohen, J.I. Proteins and cis-acting elements associated with transactivation of the varicella-zoster virus (VZV) immediate-early gene 62 promoter by VZV open reading frame 10 protein. J. Virol. 1995, 69, 4693-4701. [PubMed]

35. Smiley, J.R.; Elgadi, M.M.; Saffran, H.A. Herpes simplex virus vhs protein. Methods Enzymol. 2001, 342, 440-451. [PubMed]

36. Smiley, J.R. Herpes simplex virus virion host shutoff protein: Immune evasion mediated by a viral RNase? J. Virol. 2004, 78, 1063-1068. [CrossRef] [PubMed]

37. Strom, T.; Frenkel, N. Effects of herpes simplex virus on mRNA stability. J. Virol. 1987, 61, $2198-2207$. [PubMed]

38. Lin, H.W.; Hsu, W.L.; Chang, Y.Y.; Jan, M.S.; Wong, M.L.; Chang, T.J. Role of the UL41 protein of pseudorabies virus in host shutoff, pathogenesis and induction of TNF-alpha expression. J. Vet. Med. Sci. 2010, 72, 1179-1187. [CrossRef] [PubMed]

39. Desloges, N.; Rahaus, M.; Wolff, M.H. The varicella-zoster virus-mediated delayed host shutoff: Open reading frame 17 has no major function, whereas immediate-early 63 protein represses heterologous gene expression. Microb. Infect. 2005, 7, 1519-1529. [CrossRef] [PubMed]

40. Sato, H.; Callanan, L.D.; Pesnicak, L.; Krogmann, T.; Cohen, J.I. Varicella-zoster virus (VZV) ORF17 protein induces RNA cleavage and is critical for replication of VZV at 37 degrees C but not 33 degrees C. J. Virol. 2002, 76, 11012-11023. [CrossRef] [PubMed]

41. Boutell, C.; Everett, R.D. Regulation of alphaherpesvirus infections by the ICP0 family of proteins. J. Gen. Virol. 2013, 94, 465-481. [CrossRef] [PubMed]

42. Lanfranca, M.P.; Mostafa, H.H.; Davido, D.J. HSV-1 ICP0: An E3 ubiquitin ligase that counteracts host intrinsic and innate immunity. Cells 2014, 3, 438-454. [CrossRef] [PubMed] 
43. Parkinson, J.; Lees-Miller, S.P.; Everett, R.D. Herpes simplex virus type 1 immediate-early protein vmw110 induces the proteasome-dependent degradation of the catalytic subunit of DNA-dependent protein kinase. J. Virol. 1999, 73, 650-657. [PubMed]

44. Ferguson, B.J.; Mansur, D.S.; Peters, N.E.; Ren, H.; Smith, G.L. DNA-PK is a DNA sensor for IRF-3-dependent innate immunity. Elife 2012, 1, e00047. [CrossRef] [PubMed]

45. Moriuchi, H.; Moriuchi, M.; Smith, H.A.; Straus, S.E.; Cohen, J.I. Varicella-zoster virus open reading frame 61 protein is functionally homologous to herpes simplex virus type 1 ICP0. J. Virol. 1992, 66, 7303-7308. [PubMed]

46. Moriuchi, H.; Moriuchi, M.; Dean, H.; Cheung, A.K.; Cohen, J.I. Pseudorabies virus EPO is functionally homologous to varicella-zoster virus ORF61 protein and herpes simplex virus type 1 ICPO. Virology 1995, 209, 281-283. [CrossRef] [PubMed]

47. Maringer, K.; Elliott, G. Recruitment of herpes simplex virus type 1 immediate-early protein ICP0 to the virus particle. J. Virol. 2010, 84, 4682-4696. [CrossRef] [PubMed]

48. Dodding, M.P.; Way, M. Coupling viruses to dynein and kinesin-1. EMBO J. 2011, 30, 3527-3539. [CrossRef] [PubMed]

49. Sodeik, B.; Ebersold, M.W.; Helenius, A. Microtubule-mediated transport of incoming herpes simplex virus 1 capsids to the nucleus. J. Cell Biol. 1997, 136, 1007-1021. [CrossRef] [PubMed]

50. Döhner, K.; Wolfstein, A.; Prank, U.; Echeverri, C.; Dujardin, D.; Vallee, R.; Sodeik, B. Function of dynein and dynactin in herpes simplex virus capsid transport. Mol. Biol. Cell 2002, 13, 2795-2809. [CrossRef] [PubMed]

51. Smith, G.A.; Pomeranz, L.; Gross, S.P.; Enquist, L.W. Local modulation of plus-end transport targets herpesvirus entry and egress in sensory axons. Proc. Natl. Acad. Sci. USA 2004, 101, 16034-16039. [CrossRef] [PubMed]

52. Diefenbach, R.J.; Miranda-Saksena, M.; Douglas, M.W.; Cunningham, A.L. Transport and egress of herpes simplex virus in neurons. Rev. Med. Virol. 2008, 18, 35-51. [CrossRef] [PubMed]

53. Lyman, M.G.; Enquist, L.W. Herpesvirus interactions with the host cytoskeleton. J. Virol. 2009, 83, 2058-2066. [CrossRef] [PubMed]

54. Antinone, S.E.; Smith, G.A. Retrograde axon transport of herpes simplex virus and pseudorabies virus: a live-cell comparative analysis. J. Virol. 2010, 84, 1504-1512. [CrossRef] [PubMed]

55. Antinone, S.E.; Zaichick, S.V.; Smith, G.A. Resolving the assembly state of herpes simplex virus during axon transport by live-cell imaging. J. Virol. 2010, 84, 13019-13030. [CrossRef] [PubMed]

56. Aggarwal, A.; Miranda-Saksena, M.; Boadle, R.A.; Kelly, B.J.; Diefenbach, R.J.; Alam, W.; Cunningham, A.L. Ultrastructural visualization of individual tegument protein dissociation during entry of herpes simplex virus 1 into human and rat dorsal root ganglion neurons. J. Virol. 2012, 86, 6123-6137. [CrossRef] [PubMed]

57. Luxton, G.W.G.; Lee, J.I.-H.; Haverlock-Moyns, S.; Schober, J.M.; Smith, G.A. The pseudorabies virus VP1/2 tegument protein is required for intracellular capsid transport. J. Virol. 2006, 80, 201-209. [CrossRef] [PubMed]

58. Granzow, H.; Klupp, B.G.; Mettenleiter, T.C. Entry of pseudorabies virus: An immunogold-labeling study. J. Virol. 2005, 79, 3200-3205. [CrossRef] [PubMed]

59. Luxton, G.W.; Haverlock, S.; Coller, K.E.; Antinone, S.E.; Pincetic, A.; Smith, G.A. Targeting of herpesvirus capsid transport in axons is coupled to association with specific sets of tegument proteins. Proc. Natl. Acad. Sci. USA 2005, 102, 5832-5837. [CrossRef] [PubMed]

60. Antinone, S.E.; Shubeita, G.T.; Coller, K.E.; Lee, J.I.; Haverlock-Moyns, S.; Gross, S.P.; Smith, G.A. The herpesvirus capsid surface protein, VP26, and the majority of the tegument proteins are dispensable for capsid transport toward the nucleus. J. Virol. 2006, 80, 5494-5498. [CrossRef] [PubMed]

61. Sandbaumhüter, M.; Döhner, K.; Schipke, J.; Binz, A.; Pohlmann, A.; Sodeik, B.; Bauerfeind, R. Cytosolic herpes simplex virus capsids not only require binding inner tegument protein pUL36 but also pUL37 for active transport prior to secondary envelopment. Cell. Microbiol. 2013, 15, 248-269. [CrossRef] [PubMed]

62. Schipke, J.; Pohlmann, A.; Diestel, R.; Binz, A.; Rudolph, K.; Nagel, C.-H.; Bauerfeind, R.; Sodeik, B. The $\mathrm{C}$ terminus of the large tegument protein pUL36 contains multiple capsid binding sites that function differently during assembly and cell entry of herpes simplex virus. J. Virol. 2012, 86, 3682-3700. [CrossRef] [PubMed] 
63. Zaichick, S.V.; Bohannon, K.P.; Hughes, A.; Sollars, P.J.; Pickard, G.E.; Smith, G.A. The herpesvirus VP1/2 protein is an effector of dynein-mediated capsid transport and neuroinvasion. Cell Host Microbe 2013, 13, 193-203. [CrossRef] [PubMed]

64. Krautwald, M.; Fuchs, W.; Klupp, B.G.; Mettenleiter, T.C. Translocation of incoming pseudorabies virus capsids to the cell nucleus is delayed in the absence of tegument protein pUL37. J. Virol. 2009, 83, 3389-3396. [CrossRef] [PubMed]

65. Ojala, P.M.; Sodeik, B.; Ebersold, M.W.; Kutay, U.; Helenius, A. Herpes simplex virus type 1 entry into host cells: Reconstitution of capsid binding and uncoating at the nuclear pore complex in vitro. Mol. Cell. Biol. 2000, 20, 4922-4931. [CrossRef] [PubMed]

66. Copeland, A.M.; Newcomb, W.W.; Brown, J.C. Herpes simplex virus replication: Roles of viral proteins and nucleoporins in capsid-nucleus attachment. J. Virol. 2009, 83, 1660-1668. [CrossRef] [PubMed]

67. Abaitua, F.; Daikoku, T.; Crump, C.M.; Bolstad, M.; O'Hare, P. A single mutation responsible for temperature-sensitive entry and assembly defects in the VP1-2 protein of herpes simplex virus. J. Virol. 2011, 85, 2024-2036. [CrossRef] [PubMed]

68. Batterson, W.; Furlong, D.; Roizman, B. Molecular genetics of herpes simplex virus. VIII. Further characterization of a temperature-sensitive mutant defective in release of viral DNA and in other stages of the viral reproductive cycle. J. Virol. 1983, 45, 397-407. [PubMed]

69. Roberts, A.P.E.; Abaitua, F.; O'Hare, P.; McNab, D.; Rixon, F.J.; Pasdeloup, D. Differing roles of inner tegument proteins pUL36 and pUL37 during entry of herpes simplex virus type 1. J. Virol. 2009, 83, 105-116. [CrossRef] [PubMed]

70. Pasdeloup, D.; Blondel, D.; Isidro, A.L.; Rixon, F.J. Herpesvirus capsid association with the nuclear pore complex and viral DNA release involve the nucleoporin CAN/Nup214 and the capsid protein pUL25. J. Virol. 2009, 83, 6610-6623. [CrossRef] [PubMed]

71. Kelly, B.J.; Fraefel, C.; Cunningham, A.L.; Diefenbach, R.J. Functional roles of the tegument proteins of herpes simplex virus type 1. Virus Res. 2009, 145, 173-186. [CrossRef] [PubMed]

72. Lee, J.H.; Vittone, V.; Diefenbach, E.; Cunningham, A.L.; Diefenbach, R.J. Identification of structural protein-protein interactions of herpes simplex virus type 1. Virology 2008, 378, 347-354. [CrossRef] [PubMed]

73. Mettenleiter, T.C. Intriguing interplay between viral proteins during herpesvirus assembly or: The herpesvirus assembly puzzle. Vet. Microbiol. 2006, 113, 163-169. [CrossRef] [PubMed]

74. Vittone, V.; Diefenbach, E.; Triffett, D.; Douglas, M.W.; Cunningham, A.L.; Diefenbach, R.J. Determination of interactions between tegument proteins of herpes simplex virus type 1. J. Virol. 2005, 79, 9566-9571. [CrossRef] [PubMed]

75. Bucks, M.A.; O'Regan, K.J.; Murphy, M.A.; Wills, J.W.; Courtney, R.J. Herpes simplex virus type 1 tegument proteins VP1/2 and UL37 are associated with intranuclear capsids. Virology 2007, 361, 316-324. [CrossRef] [PubMed]

76. Möhl, B.S.; Böttcher, S.; Granzow, H.; Kuhn, J.; Klupp, B.G.; Mettenleiter, T.C. Intracellular localization of the pseudorabies virus large tegument protein pUL36. J. Virol. 2009, 83, 9641-9651. [CrossRef] [PubMed]

77. Elliott, G.; O'Hare, P. Live-cell analysis of a green fluorescent protein-tagged herpes simplex virus infection. J. Virol. 1999, 73, 4110-4119. [PubMed]

78. Donnelly, M.; Elliott, G. Nuclear localization and shuttling of herpes simplex virus tegument protein VP13/14. J. Virol. 2001, 75, 2566-2574. [CrossRef] [PubMed]

79. Hutchinson, I.; Whiteley, A.; Browne, H.; Elliott, G. Sequential localization of two herpes simplex virus tegument proteins to punctate nuclear dots adjacent to ICP0 domains. J. Virol. 2002, 76, 10365-10373. [CrossRef] [PubMed]

80. Morrison, E.E.; Stevenson, A.J.; Wang, Y.F.; Meredith, D.M. Differences in the intracellular localization and fate of herpes simplex virus tegument proteins early in the infection of Vero cells. J. Gen. Virol. 1998, 79 ( Pt 10), 2517-2528. [CrossRef] [PubMed]

81. Pomeranz, L.E.; Blaho, J.A. Modified VP22 localizes to the cell nucleus during synchronized herpes simplex virus type 1 infection. J. Virol. 1999, 73, 6769-6781. [PubMed]

82. Loret, S.; Lippe, R. Biochemical analysis of infected cell polypeptide (ICP)0, ICP4, UL7 and UL23 incorporated into extracellular herpes simplex virus type 1 virions. J. Gen. Virol. 2012, 93, 624-634. [CrossRef] [PubMed] 
83. Yao, F.; Courtney, R.J. Association of ICP0 but not ICP27 with purified virions of herpes simplex virus type 1. J. Virol. 1992, 66, 2709-2716. [PubMed]

84. Granzow, H.; Klupp, B.G.; Fuchs, W.; Veits, J.; Osterrieder, N.; Mettenleiter, T.C. Egress of alphaherpesviruses: Comparative ultrastructural study. J. Virol. 2001, 75, 3675-3684. [CrossRef] [PubMed]

85. Turcotte, S.; Letellier, J.; Lippe, R. Herpes simplex virus type 1 capsids transit by the trans-Golgi network, where viral glycoproteins accumulate independently of capsid egress. J. Virol. 2005, 79, 8847-8860. [CrossRef] [PubMed]

86. Hollinshead, M.; Johns, H.L.; Sayers, C.L.; Gonzalez-Lopez, C.; Smith, G.L.; Elliott, G. Endocytic tubules regulated by Rab GTPases 5 and 11 are used for envelopment of herpes simplex virus. EMBO J. 2012, 31, 4204-4220. [CrossRef] [PubMed]

87. Sugimoto, K.; Uema, M.; Sagara, H.; Tanaka, M.; Sata, T.; Hashimoto, Y.; Kawaguchi, Y. Simultaneous tracking of capsid, tegument, and envelope protein localization in living cells infected with triply fluorescent herpes simplex virus 1. J. Virol. 2008, 82, 5198-5211. [CrossRef] [PubMed]

88. Ibiricu, I.; Maurer, U.; Grünewald, K. Characterization of herpes simplex virus type 1 L-particle assembly and egress in hippocampal neurones by electron cryo-tomography. Cell. Microbiol. 2013, 15, 285-291. [CrossRef] [PubMed]

89. Rixon, F.J.; Addison, C.; McLauchlan, J. Assembly of enveloped tegument structures (L particles) can occur independently of virion maturation in herpes simplex virus type 1-infected cells. J. Gen. Virol. 1992, 73, 277-284. [CrossRef] [PubMed]

90. Szilagyi, J.F.; Cunningham, C. Identification and characterization of a novel non-infectious herpes simplex virus-related particle. J. Gen. Virol. 1991, 72, 661-668. [CrossRef] [PubMed]

91. del Rio, T.; DeCoste, C.J.; Enquist, L.W. Actin is a component of the compensation mechanism in pseudorabies virus virions lacking the major tegument protein VP22. J. Virol. 2005, 79, 8614-8619. [CrossRef] [PubMed]

92. Michael, K.; Böttcher, S.; Klupp, B.G.; Karger, A.; Mettenleiter, T.C. Pseudorabies virus particles lacking tegument proteins pUL11 or pUL16 incorporate less full-length pUL36 than wild-type virus, but specifically accumulate a pUL36 N-terminal fragment. J. Gen. Virol. 2006, 87, 3503-3507. [CrossRef] [PubMed]

93. Michael, K.; Klupp, B.G.; Mettenleiter, T.C.; Karger, A. Composition of pseudorabies virus particles lacking tegument protein US3, UL47, or UL49 or envelope glycoprotein E. J. Virol. 2006, 80, 1332-1339. [CrossRef] [PubMed]

94. Klopfleisch, R.; Klupp, B.G.; Fuchs, W.; Kopp, M.; Teifke, J.P.; Mettenleiter, T.C. Influence of pseudorabies virus proteins on neuroinvasion and neurovirulence in mice. J. Virol. 2006, 80, 5571-5576. [CrossRef] [PubMed]

95. Roller, R.J.; Fetters, R. The herpes simplex virus 1 UL51 protein interacts with the UL7 protein and plays a role in its recruitment into the virion. J. Virol. 2015, 89, 3112-3122. [CrossRef] [PubMed]

96. Loomis, J.S.; Courtney, R.J.; Wills, J.W. Binding partners for the UL11 tegument protein of herpes simplex virus type 1. J. Virol. 2003, 77, 11417-11424. [CrossRef] [PubMed]

97. Yeh, P.-C.; Meckes, D.G.; Wills, J.W. Analysis of the interaction between the UL11 and UL16 tegument proteins of herpes simplex virus. J. Virol. 2008, 82, 10693-10700. [CrossRef] [PubMed]

98. Harper, A.L.; Meckes, D.G.; Marsh, J.A.; Ward, M.D.; Yeh, P.-C.; Baird, N.L.; Wilson, C.B.; Semmes, O.J.; Wills, J.W. Interaction domains of the UL16 and UL21 tegument proteins of herpes simplex virus. J. Virol. 2010, 84, 2963-2971. [CrossRef] [PubMed]

99. Farnsworth, A.; Wisner, T.W.; Johnson, D.C. Cytoplasmic residues of herpes simplex virus glycoprotein $\mathrm{gE}$ required for secondary envelopment and binding of tegument proteins VP22 and UL11 to gE and gD. J. Virol. 2007, 81, 319-331. [CrossRef] [PubMed]

100. Han, J.; Chadha, P.; Meckes, D.G.; Baird, N.L.; Wills, J.W. Interaction and interdependent packaging of tegument protein UL11 and glycoprotein e of herpes simplex virus. J. Virol. 2011, 85, 9437-9446. [CrossRef] [PubMed]

101. Han, J.; Chadha, P.; Starkey, J.L.; Wills, J.W. Function of glycoprotein E of herpes simplex virus requires coordinated assembly of three tegument proteins on its cytoplasmic tail. Proc. Natl. Acad. Sci. USA 2012, 109, 19798-19803. [CrossRef] [PubMed] 
102. Klupp, B.G.; Böttcher, S.; Granzow, H.; Kopp, M.; Mettenleiter, T.C. Complex formation between the UL16 and UL21 tegument proteins of pseudorabies virus. J. Virol. 2005, 79, 1510-1522. [CrossRef] [PubMed]

103. Yeh, P.-C.; Han, J.; Chadha, P.; Meckes, D.G.; Ward, M.D.; Semmes, O.J.; Wills, J.W. Direct and specific binding of the UL16 tegument protein of herpes simplex virus to the cytoplasmic tail of glycoprotein E. J. Virol. 2011, 85, 9425-9436. [CrossRef] [PubMed]

104. Starkey, J.L.; Han, J.; Chadha, P.; Marsh, J.A.; Wills, J.W. Elucidation of the block to herpes simplex virus egress in the absence of tegument protein UL16 reveals a novel interaction with VP22. J. Virol. 2014, 88, 110-119. [CrossRef] [PubMed]

105. Cardone, G.; Newcomb, W.W.; Cheng, N.; Wingfield, P.T.; Trus, B.L.; Brown, J.C.; Steven, A.C. The UL36 tegument protein of herpes simplex virus 1 has a composite binding site at the capsid vertices. J. Virol. 2012, 86, 4058-4064. [CrossRef]

106. Coller, K.E.; Lee, J.I.-H.; Ueda, A.; Smith, G.A. The capsid and tegument of the alphaherpesviruses are linked by an interaction between the UL25 and VP1/2 proteins. J. Virol. 2007, 81, 11790-11797. [CrossRef] [PubMed]

107. Fan, W.H.; Roberts, A.P.E.; McElwee, M.; Bhella, D.; Rixon, F.J.; Lauder, R. The large tegument protein pUL36 is essential for formation of the capsid vertex-specific component at the capsid-tegument interface of herpes simplex virus 1. J. Virol. 2015, 89, 1502-1511. [CrossRef] [PubMed]

108. Klupp, B.G.; Fuchs, W.; Granzow, H.; Nixdorf, R.; Mettenleiter, T.C. Pseudorabies virus UL36 tegument protein physically interacts with the UL37 protein. J. Virol. 2002, 76, 3065-3071. [CrossRef] [PubMed]

109. Mijatov, B.; Cunningham, A.L.; Diefenbach, R.J. Residues F593 and E596 of HSV-1 tegument protein pUL36 (VP1/2) mediate binding of tegument protein pUL37. Virology 2007, 368, 26-31. [CrossRef]

110. Svobodova, S.; Bell, S.; Crump, C.M. Analysis of the interaction between the essential herpes simplex virus 1 tegument proteins VP16 and VP1/2. J. Virol. 2012, 86, 473-483. [PubMed]

111. Ko, D.H.; Cunningham, A.L.; Diefenbach, R.J. The major determinant for addition of tegument protein pUL48 (VP16) to capsids in herpes simplex virus type 1 is the presence of the major tegument protein pUL36 (VP1/2). J. Virol. 2009, 84, 1397-1405. [CrossRef] [PubMed]

112. Apcarian, A.; Cunningham, A.L.; Diefenbach, R.J. Identification of binding domains in the herpes simplex virus type 1 small capsid protein pUL35 (VP26). J. Gen. Virol. 2010, 91, 2659-2663. [CrossRef] [PubMed]

113. Jambunathan, N.; Chouljenko, D.; Desai, P.; Charles, A.-S.; Subramanian, R.; Chouljenko, V.N.; Kousoulas, K.G. Herpes simplex virus 1 protein UL37 interacts with viral glycoprotein gK and membrane protein UL20 and functions in cytoplasmic virion envelopment. J. Virol. 2014, 88, 5927-5935. [CrossRef] [PubMed]

114. Kato, K.; Daikoku, T.; Goshima, F.; Kume, H.; Yamaki, K.; Nishiyama, Y. Synthesis, subcellular localization and VP16 interaction of the herpes simplex virus type 2 UL46 gene product. Arch. Virol. 2000, 145, 2149-2162. [CrossRef] [PubMed]

115. Lin, A.E.; Greco, T.M.; Dohner, K.; Sodeik, B.; Cristea, I.M. A proteomic perspective of inbuilt viral protein regulation: pUL46 tegument protein is targeted for degradation by ICP0 during herpes simplex virus type 1 infection. Mol. Cell. Proteom. 2013, 12, 3237-3252. [CrossRef] [PubMed]

116. Fossum, E.; Friedel, C.C.; Rajagopala, S.V.; Titz, B.; Baiker, A.; Schmidt, T.; Kraus, T.; Stellberger, T.; Rutenberg, C.; Suthram, S.; et al. Evolutionarily conserved herpesviral protein interaction networks. PLoS Pathog. 2009, 5, e1000570. [CrossRef] [PubMed]

117. Zhang, Y.; Sirko, D.A.; McKnight, J.L. Role of herpes simplex virus type 1 UL46 and UL47 in alpha TIF-mediated transcriptional induction: Characterization of three viral deletion mutants. J. Virol. 1991, 65, 829-841. [PubMed]

118. Scholtes, L.D.; Yang, K.; Li, L.X.; Baines, J.D. The capsid protein encoded by U(L)17 of herpes simplex virus 1 interacts with tegument protein VP13/14. J. Virol. 2010, 84, 7642-7650. [CrossRef] [PubMed]

119. Smibert, C.A.; Popova, B.; Xiao, P.; Capone, J.P.; Smiley, J.R. Herpes simplex virus VP16 forms a complex with the virion host shutoff protein vhs. J. Virol. 1994, 68, 2339-2346. [PubMed]

120. Schmelter, J.; Knez, J.; Smiley, J.R.; Capone, J.P. Identification and characterization of a small modular domain in the herpes simplex virus host shutoff protein sufficient for interaction with VP16. J. Virol. 1996, 70, 2124-2131. [PubMed] 
121. Lam, Q.; Smibert, C.A.; Koop, K.E.; Lavery, C.; Capone, J.P.; Weinheimer, S.P.; Smiley, J.R. Herpes simplex virus VP16 rescues viral mRNA from destruction by the virion host shutoff function. EMBO J. 1996, 15, 2575-2581. [PubMed]

122. Knez, J.; Bilan, P.T.; Capone, J.P. A single amino acid substitution in herpes simplex virus type 1 VP16 inhibits binding to the virion host shutoff protein and is incompatible with virus growth. J. Virol. 2003, 77, 2892-2902. [CrossRef] [PubMed]

123. Elliott, G.; Mouzakitis, G.; O'Hare, P. VP16 interacts via its activation domain with VP22, a tegument protein of herpes simplex virus, and is relocated to a novel macromolecular assembly in coexpressing cells. J. Virol. 1995, 69, 7932-7941. [PubMed]

124. Gross, S.T.; Harley, C.A.; Wilson, D.W. The cytoplasmic tail of herpes simplex virus glycoprotein H binds to the tegument protein VP16 in vitro and in vivo. Virology 2003, 317, 1-12. [CrossRef] [PubMed]

125. Kamen, D.E.; Gross, S.T.; Girvin, M.E.; Wilson, D.W. Structural basis for the physiological temperature dependence of the association of VP16 with the cytoplasmic tail of herpes simplex virus glycoprotein H. J. Virol. 2005, 79, 6134-6141. [CrossRef] [PubMed]

126. Zhu, Q.; Courtney, R.J. Chemical cross-linking of virion envelope and tegument proteins of herpes simplex virus type 1. Virology 1994, 204, 590-599. [CrossRef] [PubMed]

127. Elliott, G.; Hafezi, W.; Whiteley, A.; Bernard, E. Deletion of the herpes simplex virus VP22-encoding gene (UL49) alters the expression, localization, and virion incorporation of ICP0. J. Virol. 2005, 79, 9735-9745. [CrossRef] [PubMed]

128. Stylianou, J.; Maringer, K.; Cook, R.; Bernard, E.; Elliott, G. Virion incorporation of the herpes simplex virus type 1 tegument protein VP22 occurs via glycoprotein E-specific recruitment to the late secretory pathway. J. Virol. 2009, 83, 5204-5218. [CrossRef] [PubMed]

129. Maringer, K.; Stylianou, J.; Elliott, G. A network of protein interactions around the herpes simplex virus tegument protein VP22. J. Virol. 2012, 86, 12971-12982. [CrossRef] [PubMed]

130. Fuchs, W.; Klupp, B.G.; Granzow, H.; Hengartner, C.; Brack, A.; Mundt, A.; Enquist, L.W.; Mettenleiter, T.C. Physical interaction between envelope glycoproteins $\mathrm{E}$ and $\mathrm{M}$ of pseudorabies virus and the major tegument protein UL49. J. Virol. 2002, 76, 8208-8217. [CrossRef] [PubMed]

131. Desai, P.J. A null mutation in the UL36 gene of herpes simplex virus type 1 results in accumulation of unenveloped DNA-filled capsids in the cytoplasm of infected cells. J. Virol. 2000, 74, 11608-11618. [CrossRef] [PubMed]

132. Fuchs, W.; Klupp, B.G.; Granzow, H.; Mettenleiter, T.C. Essential function of the pseudorabies virus UL36 gene product is independent of its interaction with the UL37 protein. J. Virol. 2004, 78, 11879-11889. [CrossRef] [PubMed]

133. Schrag, J.D.; Prasad, B.V.; Rixon, F.J.; Chiu, W. Three-dimensional structure of the HSV1 nucleocapsid. Cell 1989, 56, 651-660. [CrossRef]

134. Newcomb, W.W.; Trus, B.L.; Booy, F.P.; Steven, A.C.; Wall, J.S.; Brown, J.C. Structure of the herpes simplex virus capsid. Molecular composition of the pentons and the triplexes. J. Mol. Biol. 1993, 232, 499-511. [CrossRef] [PubMed]

135. Homa, F.L.; Huffman, J.B.; Toropova, K.; Lopez, H.R.; Makhov, A.M.; Conway, J.F. Structure of the pseudorabies virus capsid: Comparison with herpes simplex virus type 1 and differential binding of essential minor proteins. J. Mol. Biol. 2013, 425, 3415-3428. [CrossRef] [PubMed]

136. Abaitua, F.; O'Hare, P. Identification of a highly conserved, functional nuclear localization signal within the N-terminal region of herpes simplex virus type 1 VP1-2 tegument protein. J. Virol. 2008, 82, 5234-5244. [CrossRef] [PubMed]

137. Henaff, D.; Rémillard-Labrosse, G.; Loret, S.; Lippé, R. Analysis of the early steps of herpes simplex virus 1 capsid tegumentation. J. Virol. 2013, 87, 4895-4906. [CrossRef] [PubMed]

138. Leelawong, M.; Lee, J.I.; Smith, G.A. Nuclear egress of pseudorabies virus capsids is enhanced by a subspecies of the large tegument protein that is lost upon cytoplasmic maturation. J. Virol. 2012, 86, 6303-6314. [CrossRef] [PubMed]

139. Klupp, B.G.; Granzow, H.; Keil, G.M.; Mettenleiter, T.C. The capsid-associated UL25 protein of the alphaherpesvirus pseudorabies virus is nonessential for cleavage and encapsidation of genomic DNA but is required for nuclear egress of capsids. J. Virol. 2006, 80, 6235-6246. [CrossRef] [PubMed] 
140. Trus, B.L.; Newcomb, W.W.; Cheng, N.; Cardone, G.; Marekov, L.; Homa, F.L.; Brown, J.C.; Steven, A.C. Allosteric signaling and a nuclear exit strategy: Binding of UL25/UL17 heterodimers to DNA-filled HSV-1 capsids. Mol. Cell 2007, 26, 479-489. [CrossRef] [PubMed]

141. Cockrell, S.K.; Huffman, J.B.; Toropova, K.; Conway, J.F.; Homa, F.L. Residues of the UL25 protein of herpes simplex virus that are required for its stable interaction with capsids. J. Virol. 2011, 85, 4875-4887. [CrossRef] [PubMed]

142. Yang, K.; Baines, J.D. Selection of HSV capsids for envelopment involves interaction between capsid surface components pUL31, pUL17, and pUL25. Proc. Natl. Acad. Sci. USA 2011, 108, 14276-14281. [CrossRef] [PubMed]

143. Conway, J.F.; Cockrell, S.K.; Copeland, A.M.; Newcomb, W.W.; Brown, J.C.; Homa, F.L. Labeling and localization of the herpes simplex virus capsid protein UL25 and its interaction with the two triplexes closest to the penton. J. Mol. Biol. 2010, 397, 575-586. [CrossRef] [PubMed]

144. Toropova, K.; Huffman, J.B.; Homa, F.L.; Conway, J.F. The herpes simplex virus 1 UL17 protein is the second constituent of the capsid vertex-specific component required for DNA packaging and retention. J. Virol. 2011, 85, 7513-7522. [CrossRef] [PubMed]

145. Dai, X.; Gong, D.; Wu, T.-T.; Sun, R.; Zhou, Z.H. Organization of capsid-associated tegument components in Kaposi's sarcoma-associated herpesvirus. J. Virol. 2014, 88, 12694-12702. [CrossRef] [PubMed]

146. Desai, P.; Sexton, G.L.; McCaffery, J.M.; Person, S. A null mutation in the gene encoding the herpes simplex virus type 1 UL37 polypeptide abrogates virus maturation. J. Virol. 2001, 75, 10259-10271. [CrossRef] [PubMed]

147. Klupp, B.G.; Granzow, H.; Mundt, E.; Mettenleiter, T.C. Pseudorabies virus UL37 gene product is involved in secondary envelopment. J. Virol. 2001, 75, 8927-8936. [CrossRef] [PubMed]

148. Bucks, M.A.; Murphy, M.A.; O'Regan, K.J.; Courtney, R.J. Identification of interaction domains within the UL37 tegument protein of herpes simplex virus type 1. Virology 2011, 416, 42-53. [CrossRef] [PubMed]

149. Bechtel, J.T.; Shenk, T. Human cytomegalovirus UL47 tegument protein functions after entry and before immediate-early gene expression. J. Virol. 2002, 76, 1043-1050. [CrossRef] [PubMed]

150. Rozen, R.; Sathish, N.; Li, Y.; Yuan, Y. Virion-wide protein interactions of Kaposi's sarcoma-associated herpesvirus. J. Virol. 2008, 82, 4742-4750. [CrossRef] [PubMed]

151. Cappadona, I.; Villinger, C.; Schutzius, G.; Mertens, T.; von Einem, J. Human cytomegalovirus pUL47 modulates tegumentation and capsid accumulation at the viral assembly complex. J. Virol. 2015, 89, 7314-7328. [CrossRef] [PubMed]

152. Scrima, N.; Lepault, J.; Boulard, Y.; Pasdeloup, D.; Bressanelli, S.; Roche, S. Insights into herpesvirus tegument organization from structural analyses of the 970 central residues of HSV-1 UL36 protein. J. Biol. Chem. 2015, 290, 8820-8833. [CrossRef] [PubMed]

153. Tullman, J.A.; Harmon, M.E.; Delannoy, M.; Gibson, W. Recovery of an HMWP/hmwBP (pUL48/pUL47) complex from virions of human cytomegalovirus: subunit interactions, oligomer composition, and deubiquitylase activity. J. Virol. 2014, 88, 8256-8267. [CrossRef] [PubMed]

154. McLauchlan, J. The abundance of the herpes simplex virus type 1 UL37 tegument protein in virus particles is closely controlled. J. Gen. Virol. 1997, 78, 189-194. [CrossRef] [PubMed]

155. McNabb, D.S.; Courtney, R.J. Characterization of the large tegument protein (ICP1/2) of herpes simplex virus type 1. Virology 1992, 190, 221-232. [CrossRef]

156. Desai, P.; Sexton, G.L.; Huang, E.; Person, S. Localization of herpes simplex virus type 1 UL37 in the Golgi complex requires UL36 but not capsid structures. J. Virol. 2008, 82, 11354-11361. [CrossRef] [PubMed]

157. Foster, T.P.; Chouljenko, V.N.; Kousoulas, K.G. Functional and physical interactions of the herpes simplex virus type 1 UL20 membrane protein with glycoprotein K. J. Virol. 2008, 82, 6310-6323. [CrossRef] [PubMed]

158. Baines, J.D.; Ward, P.L.; Campadelli-Fiume, G.; Roizman, B. The UL20 gene of herpes simplex virus 1 encodes a function necessary for viral egress. J. Virol. 1991, 65, 6414-6424. [PubMed]

159. Hutchinson, L.; Johnson, D.C. Herpes simplex virus glycoprotein K promotes egress of virus particles. J. Virol. 1995, 69, 5401-5413. [PubMed]

160. Baines, J.D.; Ward, P.L.; Campadelli-Fiume, G.; Roizman, B. The UL20 gene of herpes simplex virus 1 encodes a function necessary for viral egress. J. Virol. 1991, 65, 6414-6424. [PubMed] 
161. Fuchs, W.; Klupp, B.; Granzow, H.; Mettenleiter, T. The UL20 gene product of pseudorabies virus functions in virus egress. J. Virol. 1997, 71, 5639-5646. [PubMed]

162. Jayachandra, S.; Baghian, A.; Kousoulas, K.G. Herpes simplex virus type 1 glycoprotein K is not essential for infectious virus production in actively replicating cells but is required for efficient envelopment and translocation of infectious virions from the cytoplasm to the extracellular space. J. Virol. 1997, 71, 5012-5024. [PubMed]

163. Lau, S.Y.; Crump, C.M. HSV-1 gM and the gK/pUL20 complex are important for the localization of gD and $\mathrm{gH} / \mathrm{L}$ to viral assembly sites. Viruses 2015, 7, 915-938. [CrossRef] [PubMed]

164. Foster, T.P.; Melancon, J.M.; Baines, J.D.; Kousoulas, K.G. The herpes simplex virus type 1 UL20 protein modulates membrane fusion events during cytoplasmic virion morphogenesis and virus-induced cell fusion. J. Virol. 2004, 78, 5347-5357. [CrossRef] [PubMed]

165. Foster, T.P.; Melancon, J.M.; Olivier, T.L.; Kousoulas, K.G. Herpes simplex virus type 1 glycoprotein K and the UL20 protein are interdependent for intracellular trafficking and trans-Golgi network localization. J. Virol. 2004, 78, 13262-13277. [CrossRef] [PubMed]

166. Pasdeloup, D.; Beilstein, F.; Roberts, A.P.E.; McElwee, M.; McNab, D.; Rixon, F.J. Inner tegument protein pUL37 of herpes simplex virus type 1 is involved in directing capsids to the trans-Golgi network for envelopment. J. Gen. Virol. 2010, 91, 2145-2151. [CrossRef] [PubMed]

167. Pasdeloup, D.; McElwee, M.; Beilstein, F.; Labetoulle, M.; Rixon, F.J. Herpesvirus tegument protein pUL37 interacts with dystonin/BPAG1 to promote capsid transport on microtubules during egress. J. Virol. 2013, 87, 2857-2867. [CrossRef] [PubMed]

168. Pitts, J.D.; Klabis, J.; Richards, A.L.; Smith, G.a.; Heldwein, E.E. Crystal structure of the herpesvirus inner tegument protein UL37 supports its essential role in control of viral trafficking. J. Virol. 2014, 88, 5462-5473. [CrossRef] [PubMed]

169. Yu, I.M.; Hughson, F.M. Tethering factors as organizers of intracellular vesicular traffic. Annu. Rev. Cell. Dev. Biol. 2010, 26, 137-156. [CrossRef] [PubMed]

170. Hew, K.; Dahlroth, S.L.; Pan, L.X.; Cornvik, T.; Nordlund, P. VP22 core domain from Herpes simplex virus 1 reveals a surprising structural conservation in both the Alpha- and Gammaherpesvirinae subfamilies. J. Gen. Virol. 2015, 96, 1436-1445. [CrossRef] [PubMed]

171. Mossman, K.L.; Sherburne, R.; Lavery, C.; Duncan, J.; Smiley, J.R. Evidence that herpes simplex virus VP16 is required for viral egress downstream of the initial envelopment event. J. Virol. 2000, 74, 6287-6299. [CrossRef] [PubMed]

172. Weinheimer, S.P.; Boyd, B.A.; Durham, S.K.; Resnick, J.L.; O'Boyle, D.R. Deletion of the VP16 open reading frame of herpes simplex virus type 1. J. Virol. 1992, 66, 258-269. [PubMed]

173. Zhang, Y.; McKnight, J.L. Herpes simplex virus type 1 UL46 and UL47 deletion mutants lack VP11 and VP12 or VP13 and VP14, respectively, and exhibit altered viral thymidine kinase expression. J. Virol. 1993, 67, 1482-1492. [PubMed]

174. Pomeranz, L.E.; Blaho, J.A. Assembly of infectious herpes simplex virus type 1 virions in the absence of full-length VP22. J. Virol. 2000, 74, 10041-10054. [CrossRef] [PubMed]

175. Kopp, M.; Klupp, B.G.; Granzow, H.; Fuchs, W.; Mettenleiter, T.C. Identification and characterization of the pseudorabies virus tegument proteins UL46 and UL47: Role for UL47 in virion morphogenesis in the cytoplasm. J. Virol. 2002, 76, 8820-8833. [CrossRef] [PubMed]

176. Fuchs, W.; Granzow, H.; Klupp, B.G.; Kopp, M.; Mettenleiter, T.C. The UL48 tegument protein of pseudorabies virus is critical for intracytoplasmic assembly of infectious virions. J. Virol. 2002, 76, 6729-6742. [CrossRef] [PubMed]

177. del Rio, T.; Werner, H.C.; Enquist, L.W. The pseudorabies virus VP22 homologue (UL49) is dispensable for virus growth in vitro and has no effect on virulence and neuronal spread in rodents. J. Virol. 2002, 76, 774-782. [CrossRef] [PubMed]

178. Fuchs, W.; Granzow, H.; Mettenleiter, T.C. A pseudorabies virus recombinant simultaneously lacking the major tegument proteins encoded by the UL46, UL47, UL48, and UL49 genes is viable in cultured cells. J. Virol. 2003, 77, 12891-12900. [CrossRef] [PubMed]

179. Duffy, C.; Lavail, J.H.; Tauscher, A.N.; Wills, E.G.; Blaho, J.A.; Baines, J.D. Characterization of a UL49-null mutant: VP22 of herpes simplex virus type 1 facilitates viral spread in cultured cells and the mouse cornea. J. Virol. 2006, 80, 8664-8675. [CrossRef] [PubMed] 
180. Brack, A.R.; Dijkstra, J.M.; Granzow, H.; Klupp, B.G.; Mettenleiter, T.C. Inhibition of virion maturation by simultaneous deletion of glycoproteins E, I, and M of pseudorabies virus. J. Virol. 1999, 73, 5364-5372. [PubMed]

181. Farnsworth, A.; Goldsmith, K.; Johnson, D.C. Herpes simplex virus glycoproteins gD and gE/gI serve essential but redundant functions during acquisition of the virion envelope in the cytoplasm. J. Virol. 2003, 77, 8481-8494. [CrossRef] [PubMed]

182. Sciortino, M.T.; Taddeo, B.; Giuffre-Cuculletto, M.; Medici, M.A.; Mastino, A.; Roizman, B. Replication-competent herpes simplex virus 1 isolates selected from cells transfected with a bacterial artificial chromosome DNA lacking only the UL49 gene vary with respect to the defect in the UL41 gene encoding host shutoff RNase. J. Virol. 2007, 81, 10924-10932. [CrossRef] [PubMed]

183. Mbong, E.F.; Woodley, L.; Dunkerley, E.; Schrimpf, J.E.; Morrison, L.A.; Duffy, C. Deletion of the herpes simplex virus 1 UL49 gene results in mRNA and protein translation defects that are complemented by secondary mutations in UL41. J. Virol. 2012, 86, 12351-12361. [CrossRef] [PubMed]

184. Ebert, K.; Depledge, D.P.; Breuer, J.; Harman, L.; Elliott, G. Mode of virus rescue determines the acquisition of VHS mutations in VP22-negative herpes simplex virus 1. J. Virol. 2013, 87, 10389-10393. [CrossRef] [PubMed]

185. Klopfleisch, R.; Teifke, J.P.; Fuchs, W.; Kopp, M.; Klupp, B.G.; Mettenleiter, T.C. Influence of tegument proteins of pseudorabies virus on neuroinvasion and transneuronal spread in the nervous system of adult mice after intranasal inoculation. J. Virol. 2004, 78, 2956-2966. [CrossRef] [PubMed]

186. Roizman, B.; Knipe, D.M.; Whitley, R.J. Herpes simplex viruses. In Fields virology, 5th ed.; Fields, B.N., Knipe, D.M., Howley, P.M., Eds.; Wolters Kluwer Health/Lippincott Williams \& Wilkins: Philadelphia, London, UK, 2007; pp. 2501-2601.

187. Baines, J.D.; Jacob, R.J.; Simmerman, L.; Roizman, B. The herpes simplex virus 1 UL11 proteins are associated with cytoplasmic and nuclear membranes and with nuclear bodies of infected cells. J. Virol. 1995, 69, 825-833. [PubMed]

188. Loomis, J.S.; Bowzard, J.B.; Courtney, R.J.; Wills, J.W. Intracellular trafficking of the UL11 tegument protein of herpes simplex virus type 1. J. Virol. 2001, 75, 12209-12219. [CrossRef] [PubMed]

189. MacLean, C.A.; Dolan, A.; Jamieson, F.E.; McGeoch, D.J. The myristylated virion proteins of herpes simplex virus type 1: Investigation of their role in the virus life cycle. J. Gen. Virol. 1992, 73, 539-547. [CrossRef] [PubMed]

190. Koshizuka, T.; Kawaguchi, Y.; Nozawa, N.; Mori, I.; Nishiyama, Y. Herpes simplex virus protein UL11 but not UL51 is associated with lipid rafts. Virus Genes 2007, 35, 571-575. [CrossRef] [PubMed]

191. Baines, J.D.; Roizman, B. The UL11 gene of herpes simplex virus 1 encodes a function that facilitates nucleocapsid envelopment and egress from cells. J. Virol. 1992, 66, 5168-5174. [PubMed]

192. Fulmer, P.A.; Melancon, J.M.; Baines, J.D.; Kousoulas, K.G. UL20 protein functions precede and are required for the UL11 functions of herpes simplex virus type 1 cytoplasmic virion envelopment. J. Virol. 2007, 81, 3097-3108. [CrossRef] [PubMed]

193. Kopp, M.; Granzow, H.; Fuchs, W.; Klupp, B.G.; Mundt, E.; Karger, A.; Mettenleiter, T.C. The pseudorabies virus UL11 protein is a virion component involved in secondary envelopment in the cytoplasm. J. Virol. 2003, 77, 5339-5351. [CrossRef] [PubMed]

194. Seo, J.-Y.; Britt, W.J. Multimerization of tegument protein pp28 within the assembly compartment is required for cytoplasmic envelopment of human cytomegalovirus. J. Virol. 2008, 82, 6272-6287. [CrossRef] [PubMed]

195. Silva, M.C.; Yu, Q.-C.; Enquist, L.; Shenk, T. Human cytomegalovirus UL99-encoded pp28 is required for the cytoplasmic envelopment of tegument-associated capsids. J. Virol. 2003, 77, 10594-10605. [CrossRef] [PubMed]

196. Leege, T.; Fuchs, W.; Granzow, H.; Kopp, M.; Klupp, B.G.; Mettenleiter, T.C. Effects of simultaneous deletion of pUL11 and glycoprotein M on virion maturation of herpes simplex virus type 1. J. Virol. 2009, 83, 896-907. [CrossRef] [PubMed]

197. Baird, N.L.; Starkey, J.L.; Hughes, D.J.; Wills, J.W. Myristylation and palmitylation of HSV-1 UL11 are not essential for its function. Virology 2010, 397, 80-88. [PubMed]

198. Meckes, D.G.; Marsh, J.A.; Wills, J.W. Complex mechanisms for the packaging of the UL16 tegument protein into herpes simplex virus. Virology 2010, 398, 208-213. [CrossRef] [PubMed] 
199. Chadha, P.; Han, J.; Starkey, J.L.; Wills, J.W. Regulated interaction of tegument proteins UL16 and UL11 from herpes simplex virus. J. Virol. 2012, 86, 11886-11898. [CrossRef] [PubMed]

200. Meckes, D.G.; Wills, J.W. Dynamic interactions of the UL16 tegument protein with the capsid of herpes simplex virus. J. Virol. 2007, 81, 13028-13036. [CrossRef] [PubMed]

201. de Wind, N.; Wagenaar, F.; Pol, J.; Kimman, T.; Berns, A. The pseudorabies virus homology of the herpes simplex virus UL21 gene product is a capsid protein which is involved in capsid maturation. J. Virol. 1992, 66, 7096-7103. [PubMed]

202. Kopp, M.; Granzow, H.; Fuchs, W.; Klupp, B.; Mettenleiter, T.C. Simultaneous deletion of pseudorabies virus tegument protein UL11 and glycoprotein M severely impairs secondary envelopment. J. Virol. 2004, 78, 3024-3034. [CrossRef] [PubMed]

203. Klupp, B.G.; Granzow, H.; Klopfleisch, R.; Fuchs, W.; Kopp, M.; Lenk, M.; Mettenleiter, T.C. Functional analysis of the pseudorabies virus UL51 protein. J. Virol. 2005, 79, 3831-3840. [CrossRef] [PubMed]

204. Nozawa, N.; Kawaguchi, Y.; Tanaka, M.; Kato, A.; Kato, A.; Kimura, H.; Nishiyama, Y. Herpes simplex virus type 1 UL51 protein is involved in maturation and egress of virus particles. J. Virol. 2005, 79, 6947-6956. [CrossRef] [PubMed]

205. Nozawa, N.; Daikoku, T.; Koshizuka, T.; Yamauchi, Y.; Yoshikawa, T.; Nishiyama, Y. Subcellular localization of herpes simplex virus type 1 UL51 protein and role of palmitoylation in Golgi apparatus targeting. J. Virol. 2003, 77, 3204-3216. [CrossRef] [PubMed]

206. Nozawa, N.; Daikoku, T.; Yamauchi, Y.; Takakuwa, H.; Goshima, F.; Yoshikawa, T.; Nishiyama, Y. Identification and characterization of the UL7 gene product of herpes simplex virus type 2. Virus Genes 2002, 24, 257-266. [CrossRef] [PubMed]

207. Fuchs, W.; Granzow, H.; Klopfleisch, R.; Klupp, B.G.; Rosenkranz, D.; Mettenleiter, T.C. The UL7 gene of pseudorabies virus encodes a nonessential structural protein which is involved in virion formation and egress. J. Virol. 2005, 79, 11291-11299. [CrossRef] [PubMed]

208. Tanaka, M.; Sata, T.; Kawaguchi, Y. The product of the herpes simplex virus 1 UL7 gene interacts with a mitochondrial protein, adenine nucleotide translocator 2. Virol. J. 2008, 5, 125. [CrossRef] [PubMed]

209. Henaff, D.; Radtke, K.; Lippe, R. Herpesviruses exploit several host compartments for envelopment. Traffic 2012, 13, 1443-1449. [CrossRef] [PubMed]

210. Hambleton, S.; Gershon, M.D.; Gershon, A.A. The role of the trans-Golgi network in varicella zoster virus biology. Cell. Mol. Life Sci. 2004, 61, 3047-3056. [CrossRef] [PubMed]

211. Guo, Y.; Sirkis, D.W.; Schekman, R. Protein sorting at the trans-Golgi network. Annu. Rev. Cell. Dev. Biol. 2014, 30, 169-206. [CrossRef] [PubMed]

212. Spang, A. The road not taken: less traveled roads from the TGN to the plasma membrane. Membranes (Basel) 2015, 5, 84-98. [CrossRef] [PubMed]

213. Gallon, M.; Cullen, P.J. Retromer and sorting nexins in endosomal sorting. Biochem. Soc. Trans. 2015, 43, 33-47. [CrossRef] [PubMed]

214. Lu, L.; Hong, W. From endosomes to the trans-Golgi network. Semin. Cell Dev. Biol. 2014, 31, 30-39. [CrossRef] [PubMed]

215. Avitabile, E.; Di Gaeta, S.; Torrisi, M.R.; Ward, P.L.; Roizman, B.; Campadelli-Fiume, G. Redistribution of microtubules and Golgi apparatus in herpes simplex virus-infected cells and their role in viral exocytosis. J. Virol. 1995, 69, 7472-7482. [PubMed]

216. Campadelli, G.; Brandimarti, R.; Di Lazzaro, C.; Ward, P.L.; Roizman, B.; Torrisi, M.R. Fragmentation and dispersal of Golgi proteins and redistribution of glycoproteins and glycolipids processed through the Golgi apparatus after infection with herpes simplex virus 1. Proc. Natl. Acad. Sci. USA 1993, 90, 2798-2802. [CrossRef] [PubMed]

217. Beitia Ortiz de Zarate, I.; Cantero-Aguilar, L.; Longo, M.; Berlioz-Torrent, C.; Rozenberg, F. Contribution of endocytic motifs in the cytoplasmic tail of herpes simplex virus type 1 glycoprotein $B$ to virus replication and cell-cell fusion. J. Virol. 2007, 81, 13889-13903. [CrossRef] [PubMed]

218. Alconada, A.; Bauer, U.; Sodeik, B.; Hoflack, B. Intracellular traffic of herpes simplex virus glycoprotein $\mathrm{gE}$ : Characterization of the sorting signals required for its trans-Golgi network localization. J. Virol. 1999, 73, 377-387. [PubMed] 
219. Nixdorf, R.; Klupp, B.G.; Mettenleiter, T.C. Role of the cytoplasmic tails of pseudorabies virus glycoproteins B, E and $\mathrm{M}$ in intracellular localization and virion incorporation. J. Gen. Virol. 2001, 82, 215-226. [CrossRef] [PubMed]

220. Van Minnebruggen, G.; Favoreel, H.W.; Nauwynck, H.J. Internalization of pseudorabies virus glycoprotein B is mediated by an interaction between the YQRL motif in its cytoplasmic domain and the clathrin-associated AP-2 adaptor complex. J. Virol. 2004, 78, 8852-8859. [CrossRef] [PubMed]

221. McMillan, T.N.; Johnson, D.C. Cytoplasmic domain of herpes simplex virus gE causes accumulation in the trans-Golgi network, a site of virus envelopment and sorting of virions to cell junctions. J. Virol. 2001, 75, 1928-1940. [CrossRef] [PubMed]

222. Crump, C.M.; Bruun, B.; Bell, S.; Pomeranz, L.E.; Minson, T.; Browne, H.M. Alphaherpesvirus glycoprotein $\mathrm{M}$ causes the relocalization of plasma membrane proteins. J. Gen. Virol. 2004, 85, 3517-3527. [CrossRef] [PubMed]

223. Ren, Y.; Bell, S.; Zenner, H.L.; Lau, S.Y.; Crump, C.M. Glycoprotein M is important for the efficient incorporation of glycoprotein H-L into herpes simplex virus type 1 particles. J. Gen. Virol. 2012, 93, 319-329. [CrossRef] [PubMed]

224. Votteler, J.; Sundquist, W.I. Virus budding and the ESCRT pathway. Cell Host Microbe 2013, 14, $232-241$. [CrossRef] [PubMed]

225. Crump, C.M.; Yates, C.; Minson, T. Herpes simplex virus type 1 cytoplasmic envelopment requires functional Vps4. J. Virol. 2007, 81, 7380-7387. [CrossRef] [PubMed]

226. Calistri, A.; Sette, P.; Salata, C.; Cancellotti, E.; Forghieri, C.; Comin, A.; Gottlinger, H.; Campadelli-Fiume, G.; Palu, G.; Parolin, C. Intracellular trafficking and maturation of herpes simplex virus type $1 \mathrm{gB}$ and virus egress require functional biogenesis of multivesicular bodies. J. Virol. 2007, 81, 11468-11478. [CrossRef] [PubMed]

227. Pawliczek, T.; Crump, C.M. Herpes simplex virus type 1 production requires a functional ESCRT-III complex but is independent of TSG101 and ALIX expression. J. Virol. 2009, 83, 11254-11264. [CrossRef] [PubMed]

228. Kharkwal, H.; Smith, C.G.; Wilson, D.W. Blocking ESCRT-mediated envelopment inhibits microtubule-dependent trafficking of alphaherpesviruses in vitro. J. Virol. 2014, 88, 14467-14478. [CrossRef] [PubMed]

229. Tandon, R.; AuCoin, D.P.; Mocarski, E.S. Human cytomegalovirus exploits ESCRT machinery in the process of virion maturation. J. Virol. 2009, 83, 10797-10807. [CrossRef] [PubMed]

230. Lee, C.P.; Liu, P.T.; Kung, H.N.; Su, M.T.; Chua, H.H.; Chang, Y.H.; Chang, C.W.; Tsai, C.H.; Liu, F.T.; Chen, M.R. The ESCRT machinery is recruited by the viral BFRF1 protein to the nucleus-associated membrane for the maturation of Epstein-Barr virus. PLoS Pathog. 2012, 8, e1002904. [CrossRef] [PubMed]

231. Henne, W.M.; Buchkovich, N.J.; Emr, S.D. The ESCRT pathway. Dev. Cell 2011, 21, 77-91. [CrossRef] [PubMed]

232. Agromayor, M.; Martin-Serrano, J. Knowing when to cut and run: Mechanisms that control cytokinetic abscission. Trends Cell Biol. 2013, 23, 433-441. [CrossRef] [PubMed]

233. Calistri, A.; Munegato, D.; Toffoletto, M.; Celestino, M.; Franchin, E.; Comin, A.; Sartori, E.; Salata, C.; Parolin, C.; Palu, G. Functional interaction between the ESCRT-I component TSG101 and the HSV-1 tegument ubiquitin specific protease. J. Cell. Physiol. 2015, 230, 1794-1806. [CrossRef] [PubMed]

234. Hogue, I.B.; Bosse, J.B.; Hu, J.-R.; Thiberge, S.Y.; Enquist, L.W. Cellular mechanisms of alpha herpesvirus egress: Live cell fluorescence microscopy of pseudorabies virus exocytosis. PLoS Pathog. 2014, 10, e1004535. [CrossRef] [PubMed]

235. Miranda-Saksena, M.; Boadle, R.A.; Aggarwal, A.; Tijono, B.; Rixon, F.J.; Diefenbach, R.J.; Cunningham, A.L. Herpes simplex virus utilizes the large secretory vesicle pathway for anterograde transport of tegument and envelope proteins and for viral exocytosis from growth cones of human fetal axons. J. Virol. 2009, 83, 3187-3199. [CrossRef] [PubMed]

236. Cheng, S.B.; Ferland, P.; Webster, P.; Bearer, E.L. Herpes simplex virus dances with amyloid precursor protein while exiting the cell. PLoS ONE 2011, 6, e17966. [CrossRef] [PubMed]

237. Remillard-Labrosse, G.; Mihai, C.; Duron, J.; Guay, G.; Lippe, R. Protein kinase D-dependent trafficking of the large herpes simplex virus type 1 capsids from the TGN to plasma membrane. Traffic 2009, 10, 1074-1083. [CrossRef] [PubMed] 
238. Roberts, K.L.; Baines, J.D. Myosin Va enhances secretion of herpes simplex virus 1 virions and cell surface expression of viral glycoproteins. J. Virol. 2010, 84, 9889-9896. [CrossRef] [PubMed]

239. Griffiths, S.J.; Koegl, M.; Boutell, C.; Zenner, H.L.; Crump, C.M.; Pica, F.; Gonzalez, O.; Friedel, C.C.; Barry, G.; Martin, K.; et al. A systematic analysis of host factors reveals a Med23-interferon- $\lambda$ regulatory axis against herpes simplex virus type 1 replication. PLoS Pathog. 2013, 9, e1003514. [CrossRef] [PubMed]

240. Johns, H.L.; Gonzalez-Lopez, C.; Sayers, C.L.; Hollinshead, M.; Elliott, G. Rab6 dependent post-Golgi trafficking of HSV1 envelope proteins to sites of virus envelopment. Traffic 2014, 15, 157-178. [CrossRef] [PubMed] (c) ()

(C) 2015 by the authors; licensee MDPI, Basel, Switzerland. This article is an open access article distributed under the terms and conditions of the Creative Commons by Attribution (CC-BY) license (http://creativecommons.org/licenses/by/4.0/). 